\title{
1999 Alfred Bader Award Lecture From early developments in multi-step organic synthesis on solid phases to multi-nuclear phthalocyanines ${ }^{1}$
}

\author{
Clifford C. Leznoff
}

\begin{abstract}
Early developments in solid phase organic synthesis are traced. Particular emphasis is placed on the use of cross-linked polystyrene in the first general method of monoblocking symmetrical difunctional compounds. The monoprotected polymer-bound symmetrical starting materials were then used in multi-step syntheses of a variety of compounds, particularly insect pheromones. Asymmetric synthesis on polymer supports was demonstrated. Diels-Alder and 1,3-dipolar additions on polymer supports proceeded readily as did macrocyclic formation of porphyrins and phthalocyanines. All of these reactions clearly showed that most organic chemical reactions could be performed on solid phases and laid the basis for the development of combinatorial chemistry. The first unsymmetrical phthalocyanine was prepared using the solid phase method and this led eventually to solution phase methods of preparing bi-, tri-, tetra-, and even a dendritic-like pentanuclear phthalocyanine.
\end{abstract}

Key Words: solid phase organic synthesis (SPOS), phthalocyanines.

Résumé : On retrace les développements de la synthèse organique en phase solide. On insiste sur l'utilisation du polystyrène réticulé dans la première méthode générale de bloquer une seule des deux fonctions de composés bifonctionnels symétriques. Les produits de départ symétriques reliés par une seule liaison à un polymère étaient ensuite utilisés dans des synthèses en plusieurs étapes d'une grande variété de composés, en particulier des phéromones d'insectes. La possibilité de réaliser des synthèses asymétriques sur des polymères solides a été démontrée. On a aussi montré que, sur des supports solides, on peut effectuer facilement des additions de Diels-Alder et des additions 1,3dipolaires ainsi que la formation de macrocycles, comme les porphyrines et les phtalocyanines. Toutes ces réactions ont clairement démontré que la plupart des réactions organiques peuvent être réalisées en phases solides et ont servi de base au développement de la chimie combinatoire. La première phtalocyanine non symétrique a été préparée en faisant appel à la phase solide et ceci a conduit aux préparations, par des méthodes de phase en solution, de bi-, tri-, tétra- et même d'une phtalocyanine pentanucléaire de nature dendritique.

Mots clés : synthèse organique en phase solide (SOPS), phtalocyanines.

[Traduit par la Rédaction]

\section{Introduction}

Organic chemists have long been wedded to the practice of performing chemical reactions in homogeneous media. Hence, the idea that organic reactions could be performed on insoluble polymer supports was indeed revolutionary $(1,2)$. This concept was initially applied to solid phase synthesis of polypeptides $(1,3)$, polynucleotides (4-6), and later polysaccharides (7). These topics have been reviewed often $(8-10)$. The general advantage of organic synthesis on insoluble

C.C. Leznoff. ${ }^{2}$ Department of Chemistry, York University, Toronto, ON M3J 1P3, Canada.

${ }^{1}$ This paper is based on the Alfred Bader Award lecture presented May 30, 1999 by Professor Leznoff at the 82 nd Annual Conference of the Canadian Society for Chemistry, Toronto, Ontario.

${ }^{2}$ Telephone: (416) 736-2100 ext. 33838. Fax: (416) 736-5936. e-mail: leznoff@yorku.ca polymer supports (usually cross-linked polystyrene) is particularly favourable for repetitive synthesis of like units such as the sequential addition of amino acids to a polymer support. Thus, polypeptides can be prepared on solid phases, whereby the only mechanical operations involved are stirring (or shaking), filtration, and washing. In some respects, these repetitive syntheses are easy in that only a very few different reactions at room temperature are required. It is so easy, in fact, that the process was automated even using precomputer technology (11). Even so, difficulties abounded; however, multiple parallel synthesis of polypeptides using computer-controlled robotic systems is now routine $(12,13)$.

During this era, reagents attached to insoluble polymer supports, useful for organic synthesis, were developed. The work of Patchornik's group $(14,15)$ on the use of reagents for polypeptide synthesis was noteworthy. Polymer-bound reagents $(15,16)$ and catalysts $(16,17)$ in which the organic reagent or catalyst is bound to the polymer (with the organic substrate always remaining in solution) has found its place in many applications but is beyond the scope of this article. 
Scheme 1.

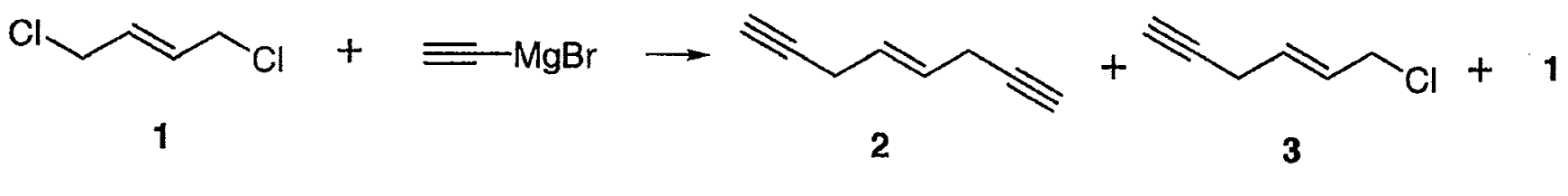

Inseparable Mixture

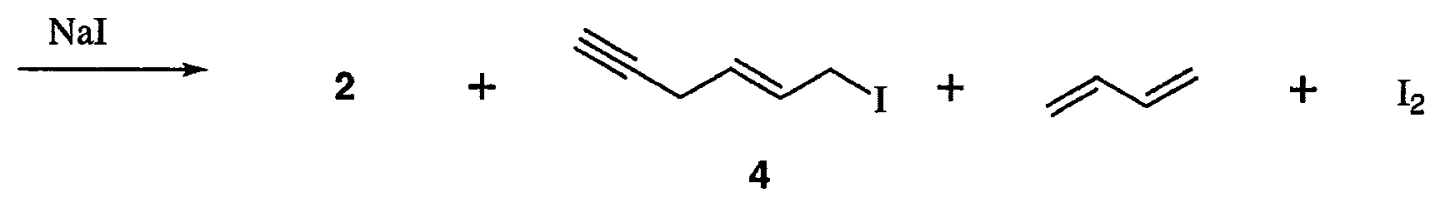

A post-doctoral fellowship in Letsinger's laboratory $(2,4)$ in 1964 piqued my curiosity to the possibility of using polymer supports in organic synthesis. Coincidentally, during our research project on the synthesis of annulenes in another post-doctoral sojourn in Sondheimer's group (18), we were faced with the problem of reacting trans-1,4-dichloro-2butene (1) with ethynyl magnesium bromide. Invariably, an inseparable mixture of 1 , the bis reacted product trans-4octen-1,7-diyne (2) and the desired trans-6-chloro-4-hexen$1-y n e(3)$ was obtained. These compounds had very similar boiling points and they could not be separated by distillation. Ultimately, conversion of the mixture of 1-3 with $\mathrm{NaI}$ led to $I_{2}$, butadiene, 2 , and trans-6-iodo-4-hexen-1-yne (4) which was separable by distillation (Scheme 1). This problem led to the germination of an idea that insoluble polymer supports could be an advantage in addressing the whole concept of monoreactions of symmetrically difunctionalized organic compounds.

\section{Insoluble polymers supports as blocking groups of symmetrically disubstituted compounds}

Solid phase organic synthesis (SPOS) usually refers to general organic synthesis on polymer-supports, outside the repetitive syntheses of polypeptides, polynucleotides, and polysaccharides. The synthesis of a threaded rotaxane in 1967 (19) on a polymer support probably represents the first example of SPOS. Our own early efforts focussed on the use of polymer supports as monoblocking agents of completely symmetrical difunctional compounds. Monoreactions of reagents such as acetyl chloride with a compound such as 1,10 -decanediol (5) in a $1: 1$ ratio would give $25 \%$ of the bis reacted product, $50 \%$ of the desired monoreacted product, and $25 \%$ of unreacted starting material. A large excess of (5), for example, would give mainly the desired monoreacted product and unreacted starting material but separating the minor product (the monoreacted product) from a sea of unreacted starting material could be difficult. This separation could be readily achieved, however, by simple filtration if the monoreacted product remained attached to an insoluble polymer and "fished out" of the excess starting material which could be recovered. The process would be particularly important for the longer chain symmetrical difunctional compounds such as $\mathbf{5}$, as short chain monoreaction products of say ethylene glycol could be achieved by other methods such as ring opening reactions of ethylene oxide. Thus treatment of polymer-bound ${ }^{3}$ phenylacetylchloride (6) (20) with a large excess of symmetrical diols $(5, n=2,4,6,8$, 10) gave the polymer-bound monoprotected diols (7). Subsequent reaction of 7 with chlorotriphenylmethane $(\mathrm{TrCl})$ or dihydropyran (dhp) gave polymer-protected monoether 8 . Cleavage of 8 with $\mathrm{NH}_{4} \mathrm{OH}$ gave polymer-bound phenylacetic acid (9) and the liberated monoprotected ethers of the symmetrical diols $(\mathbf{1 0})(21,22)$ (Scheme 2). Recovered 9 was converted back to 6 but the synthesis of $10(n=10)$ on once used 9 gave $\mathbf{1 0}$ in lower yield.

In order to obtain a more recyclable polymer, a polymerbound trityl chloride ${ }^{3}$ (11) was prepared by our direct lithiation method $(23,24)$. Treatment of 11 with symmetrical diols $(5, n=4,7,10)$ gave the polymer-bound monotrityl ether 12. Acetylation gave the polymer-bound monotrityl monoacetates (13) which on acid cleavage gave polymerbound trityl alcohol (14) and the desired symmetrical diol monoacetates $(15)(23,24)$ (Scheme 3$)$. Polymer 14 was readily recyclable to give products in undiminished yield from used 14.

The successful monoprotection of symmetrical diols encouraged us to explore the monoprotection of other symmetrical difunctional compounds, particularly symmetrical dialdehydes. For this purpose, a polymer-bound 1,2-diol (16) was developed (25). Treatment of 16 with terephthalaldehyde (17) gave the polymer-bound monoacetal (18). It should be noted that such a reaction in solution gives only bis acetal and unreacted 17 as the mono product is normally more reactive

\footnotetext{
${ }^{3}$ The use of a ${ }^{\oplus}$ used by Merrifield, Letsinger and others to represent the polymer has in recent times been replaced by a solid sphere. It is unlikely that the $\mathrm{P}$ could be confused for phosphate in the context used and the more currently used symbol, the solid grey or black sphere, could also be confused with current representations of solid metallic clusters, the latter use being more reasonable as the solid ball is solid like the cluster. In addition, the P can be replaced by Si for silica polymers and PEG for polyethylene glycol polymers, etc., and, hence, is more flexible. In this paper the polymer is, polystyrene, cross-linked with 1-3\% divinylbenzene. In the trityl containing polymer (11), one phenyl group of the polymer is actually part of the trityl group.
} 
Scheme -

$$
\text { (P) }-\mathrm{CH}_{2} \mathrm{COCl}+\mathrm{HO}\left(\mathrm{CH}_{2}\right)_{n} \mathrm{OH}
$$

6

5<smiles>[Y]C1CC1</smiles>

(P) $-\mathrm{CH}_{2} \mathrm{CO}_{2}\left(\mathrm{CH}_{2}\right)_{n} \mathrm{OH}$

7

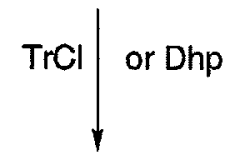

(P) $-\mathrm{CH}_{2} \mathrm{CO}_{2}\left(\mathrm{CH}_{2}\right)_{n} \mathrm{OR}$

$8 \quad \mathrm{R}=\mathrm{Tr}$ or Thp $n=2,4,6,8,10$

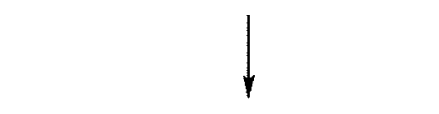

$$
\begin{array}{cc}
\left(\mathrm{P}-\mathrm{CH}_{2} \mathrm{CO}_{2} \mathrm{H}\right. & +\mathrm{HO}\left(\mathrm{CH}_{2}\right)_{n} \mathrm{OR} \\
9 & 10 \begin{array}{c}
\mathrm{R} \\
n=2,4,6,8,10 \\
n=2,4
\end{array}
\end{array}
$$

Scheme 3.

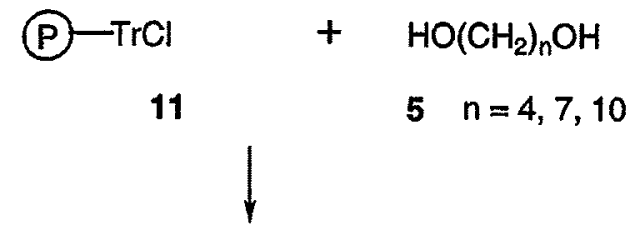

(P) $-\mathrm{TrO}\left(\mathrm{CH}_{2}\right)_{n} \mathrm{OH}$

12

$\mathrm{Ac}_{2} \mathrm{O}$

(P) $-\mathrm{TrO}\left(\mathrm{CH}_{2}\right)_{n} \mathrm{OA}$

$13 \mathrm{R}=\mathrm{OAC}$

$n=4,7,10$

$\mathrm{H}^{+}$

(P) $-\mathrm{TrOH}+\mathrm{HO}\left(\mathrm{CH}_{2}\right)_{n} \mathrm{OAC}$

14

$15 n=4,7,10$

Scheme 4.<smiles>CC=Cc1ccccc1</smiles>

(P)

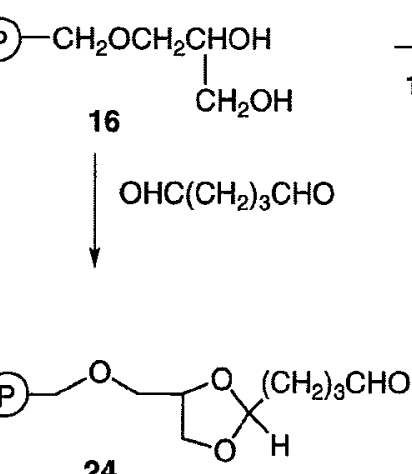

24

1. $\mathrm{PhMgBr}$

2. $\mathrm{H}^{+}$

$\mathrm{PhCH}=\mathrm{CH}\left(\mathrm{CH}_{2}\right)_{3} \mathrm{CHO}$

25

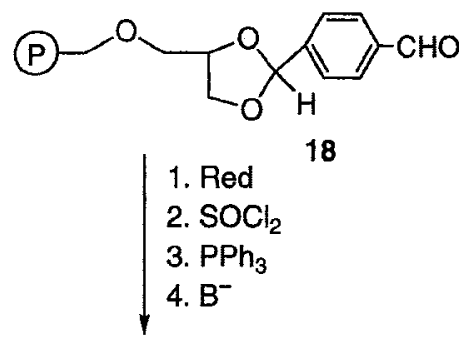<smiles>Pc1ccccc1</smiles>

19<smiles>[Te][I+]</smiles><smiles>O=Cc1ccccc1</smiles>

20<smiles>[3H][I+]</smiles>

$16+p \mathrm{HOCPhCH}=\mathrm{CHPh} p \mathrm{CHO}$ 
Scheme 5.<smiles>O=Cc1cccc(C=CC(=O)c2cccc(C=Cc3cccc(C4OCC(COCc5ccccc5)O4)c3)c2)c1</smiles>

Scheme 6.<smiles>OCC(O)COCc1ccccc1</smiles><smiles>O=C1CCCC(=O)C1</smiles><smiles>O=C1CCCC2(C1)OCC(COCc1ccccc1)O2</smiles>

37<smiles>O=C1C=C(c2ccccc2)CCC1</smiles>

38<smiles>CC(=O)c1ccc(C2(C)OCC(COCc3ccccc3)O2)cc1</smiles>

32

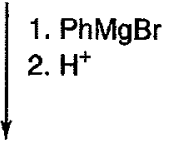<smiles>CC1(c2ccc(C(C)(O)c3ccccc3)cc2)OCC(COCc2ccccc2)O1</smiles>

33<smiles>CC1(c2ccccc2)OCC(COCc2ccc(C(C)(C)c3ccc(C=CC=Cc4ccccc4)cc3)cc2)O1</smiles>

35<smiles>[3H][IH+]</smiles><smiles>COc1ccc(C(C)C=Cc2ccccc2)cc1</smiles>

$16+$
36<smiles>C=CC(C)(C)c1ccc(OC)cc1</smiles>

34 that the starting dial, containing two electron-withdrawing groups. Conversion of $\mathbf{1 8}$ to a polymer-bound Wittig reagent (19) in four steps and further reaction with symmetrical dial 17 led to polymer-bound 20. Acid cleavage of 20 gave 16, that could be recovered, and the symmetrical diformylstilbene (21) in the first multi-step (7 reactions) SPOS on polymer supports (26). Interestingly $\mathbf{1 8}$ was also converted to a helicene (27). A linear conjugated symmetrical dialdehyde, 2,7-dimethyl-2,4,6-octatrien-1,7-dial reacted with 16 to give the polymer-bound monoprotected 22 . The Wittig reaction of 22 gave the polymer-bound polyenes 23 , which on acid cleavage provided conjugated aldehydes, useful in carotenoid synthesis (28). Even symmetrical aliphatic dialdehydes may be monoprotected using 16 giving polymer-bound 24, which with $\mathrm{PhMgBr}$ and acid cleavage, gives 25 (29) (Scheme 4). The symmetrical isophthalaldehyde can be monoprotected with 16 as well to give the polymer-bound monoblocked acetal 26. Wittig reactions on $\mathbf{2 6}$ give the formyl diene 28 via polymerbound butadiene 27 , oximation of 26 gives a polymer-bound acetal oxime which yields monooxime 29 , while an aldol con- densation of $\mathbf{2 6}$ gives polymer-bound chalcone $\mathbf{3 0}$ and ultimately formyl chalcone 31 (25) (Scheme 5). In all cases recovered $\mathbf{1 6}$ is fully recyclable.

These formyl compounds 28, 29, and 31 and their $p$ analogs (25) are difficult to prepare in solution. Symmetrical diketones can be monoprotected with 16. Thus, $p$-diacetylbenzene reacts with 16 to give the polymer-bound monoacetal (ketal) 32, which with $\mathrm{PhMgBr}$ gives 33 and acid cleavage gives the $p$-acetylstyrene $34(30)$. Alternatively, the Wittig reaction of $\mathbf{3 2}$ gives polymer 35 which liberates a $p$ acetylstilbene (36) (31). Symmetrical cyclic diketones such as 1,3-cyclohexanedione react with polymer 16 to give the monoprotected 37 which on Grignardization and acid cleavage liberates 3-phenyl-2-cylohexen-1-one (38) (Scheme 6). Again polymer 16 is recovered for reuse with undiminished capacity. Recently, polymer $\mathbf{1 6}$ has been used in palladium coupling reactions (32).

Other polymer-bound 1,2 and 1,3-diols were also used in similar reactions but the polymers were not always recyclable (33). Interestingly, the reverse of the procedures described 
Scheme 7.

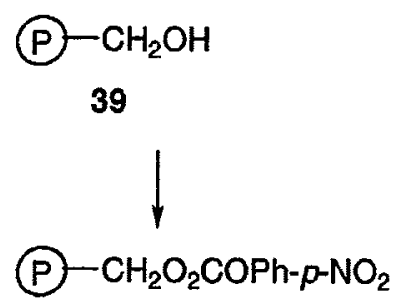

40<smiles>NCCN(CCN)C(=O)OCc1ccccc1</smiles>

42<smiles>NCCCNC(=O)OCc1ccccc1</smiles>

$43 \mathrm{R}=\mathrm{PhCO}$ or Ts $n=4,6,8,10,12$

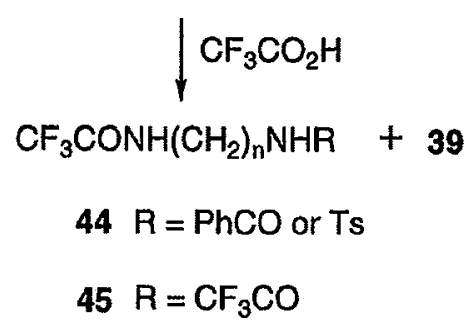

in Schemes 4-6 has been described recently in which a polymer-bound aldehyde has been used to monoblock symmetrical tetraols (34). Polymer-bound boronic acids have been used to selectively extract cis-diols from mixtures (35).

Polymer supports have been used to monoprotect symmetrical diamines. Thus, polymer-bound benzyl alcohol (39) on treatment with $p$-nitrophenyl chloroformate yielded the polymer-bound carbonate (40) which on reaction with the symmetrical diamines $(41, n=4,6,8,10,12)$ yielded the polymer-bound monoprotected carbamates (43). Subsequent treatment with benzoyl chloride or $p$-toluenesulfonyl chloride ( $\mathrm{TsCl}$ ) gave polymers 43 . Treatment of 43 with trifluoroacetic acid gave recyclable polymer 39 , the desired unsymmetrical amides $(44, n=4,6,8,10,12)$, and some bistrifluoroacetamide (45) of their respective diamines (36) (Scheme 7). The trifluoroacetamido groups of 44 are easily cleaved by mild base. Some recent examples using polymerbound monoprotected symmetrical diamines in SPOS have been reported (37).

Symmetrical diesters, diacids, and diacid chlorides can be monoblocked most readily using diacid chlorides, which is general for both linear and aromatic diacid chlorides. Thus, polymer 39 readily reacts with a series of diacid chlorides
$\left(\mathrm{ClOC}\left(\mathrm{CH}_{2}\right)_{n} \mathrm{COCl}(n=2,3,4,8)\right)$ to give the polymerbound monoester mono-acid chlorides (46). These versatile monoblocked derivatives (46) may be treated with amines to give polymer-bound ester amides (47) which can be cleaved and esterified to the free methyl ester amides (48). Alternatively, $46(n=8)$ may be reduced selectively to methyl 10 hydroxydecanoic acid $(49)(38,39)$. Treatment of 46 with phenyl or butylmanganese iodide (40) gave polymers (50) resulting from selective addition to the acid chloride. Cleavage and methylation readily yielded 51 (41). In all cases, 39 was recovered and was recyclable. Similarly, aromatic diacid chlorides such as terephthaloyl and isophthaloyl chloride provided the ester alcohols $\mathbf{5 2}$ and aromatic ester amides 53 (Scheme 8). Polymer-bound monoester succinic acid was formed via succinic anlydride (42) and recently the malonic analog via Meldrum's acid (43) and other activated acids (44) were monoprotected using polymers. Only rigid diacids such as fumaric and 2-butyne-1,4-dioic acid can be reacted directly with a polymer support $(45,46)$ as intraresin reactions strongly interfere $(47,48)$.

Dihydroxy aromatic compounds are also readily monoprotected using a polymer-bound benzoyl chloride (54). Thus, treatment of $\mathbf{5 4}$ with 2,7-dihydroxynaphthalene (55) gave the polymer-bound monoester mononaphthol (56), which on reaction with diazomethane and cleavage gave recovered polymer-bound benzoic acid (57) and 7-methoxy-2-naphthol (58). Simpler phenols such as resorcinol and hydroquinone also gave polymer-bound monoprotected phenols 59 which on alkylation gave 60 and cleavage yielded the $m$ - or $p$ monoalkyl ethers of phenol (61) (50) (Scheme 9).

In all of the above examples, it is possible for the polymer support to react with both ends of the insoluble polymer support, the so called "double binding" problem. This problem has been discussed in some of the earliest reviews on SPOS (47-49) and in more recent reviews (49). Double binding can usually be diminished greatly by using a vast excess of starting symmetrical difunctional compound and indeed most of the examples listed show minimal double binding, but symmetrical diols can give up to $40 \%$ double binding and aliphatic diacids up to $100 \%$ double binding (47-50). Even when double binding occurs, it usually doesn't interfere in the reactions of SPOS but does reduce capacity. Although double binding can be eliminated by putting the polymer-bound functional group at a cross-linked position, capacity is reduced $(23,51)$.

New methods of monoprotecting symmetrical difunctional compounds in solution have been developed, particularly with respect to diols (52-55), tetraols (56), dihydroxyaromatic compounds $(57,58)$, dials $(59,60)$, diones $(61)$, diamines $(62-64)$, diesters $(65,66)$, diacids $(67,68)$, and dihalides $(69,70)$. Some of these methods still rely on statistical strategies using excess substrate $(69,70)$; others rely on specific properties of the monoprotected products such as precipitation ( $52 a)$, solubility (54b), and enzymatic activity (55), while additional routes feature reactivity profiles (53), solid phase catalysis $(54 c, 65,68)$, or alternative synthesis (69). All of these solution methods are, unfortunately, applicable not only to a specific symmetrical difunctional group, but to defined sub classes of that group and hence, are not general methods like the polymer support method. Despite this, specific methods are used more generally both 
Scheme 8.<smiles>CC(=O)OCc1ccc(C(=O)OCc2ccc(C(=O)Cl)cc2)cc1</smiles>

39<smiles>O=C(O)c1cccc(C(=O)O)c1</smiles><smiles>CC(=O)c1cccc(CO)c1</smiles>

52<smiles>C1CC1</smiles>

(P) $-\mathrm{CH}_{2} \mathrm{O}_{2} \mathrm{C}\left(\mathrm{CH}_{2}\right)_{n} \mathrm{C}(\mathrm{OH}) \mathrm{R}_{2} \longrightarrow$

50<smiles>C1CCCCC1</smiles>

RMnI
$39+\mathrm{CH}_{3} \mathrm{O}_{2} \mathrm{C}\left(\mathrm{CH}_{2}\right)_{n} \mathrm{C}(\mathrm{OH}) \mathrm{R}_{2}$

$51 \mathrm{R}=\mathrm{Ph}, \mathrm{Bu}$
$39+\mathrm{CH}_{3} \mathrm{O}_{2} \mathrm{C}\left(\mathrm{CH}_{2}\right)_{9} \mathrm{OH}$

49
$39+\mathrm{CH}_{3} \mathrm{O}_{2} \mathrm{C}\left(\mathrm{CH}_{2}\right)_{n}$ CONRR'

$$
48 \begin{aligned}
n & =2,3,4,8 \\
R & =R^{\prime}=C_{3} \\
R & =R^{\prime}=H \\
R & =P h, R^{\prime}=H
\end{aligned}
$$

Scheme 9.<smiles>O=C(Cl)C(=O)Oc1cccc(O)c1</smiles>

59

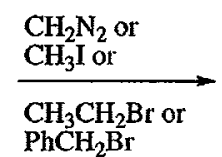

$\mathrm{PhCH}_{2} \mathrm{Br}$

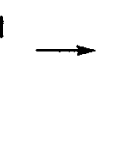

55<smiles>O=C([Se])c1ccc2ccc(O)cc2c1</smiles>

56

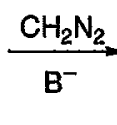

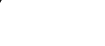

57

(P) $\mathrm{CO}_{2} \mathrm{H}+$<smiles>COc1ccc2ccc(O)cc2c1</smiles>

58
(P)<smiles>O=C(O)c1cccc(O)c1</smiles>

60

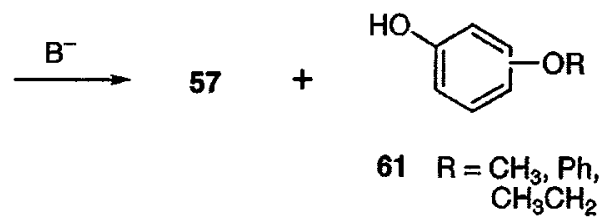

academically and industrially where a single particular difunctional compound can be monoblocked by methods peculiar to that compound. With the advent of combinatorial chemistry (71-73), it is important to have a general method of monoprotection of symmetrical substrates for elaboration into the preparation of chemistry libraries and this method is being used now in this context $(37 b, c)$.

\section{Multi-step solid phase organic synthesis}

The synthesis of polypeptides, polynucleotides, and polysaccharides all depend on the selective attachment to the polymer support of a difunctional compound containing two different functional goups. The monoblocking of symmetrical difunctional compounds, having two identical functional groups, on solid phases opened the way to using simple inexpensive materials in multi-step solid phase organic synthesis (SPOS). Although 21 (Scheme 4) was synthesized before in a multi-step synthesis, our major effort was devoted to SPOS of insect pheromones (74-80), which has been reviewed (77) previously. Three routes to insect pheromones on solid phases were paramount. Thus, polymer-bound trityl-blocked symmetrical diols (12) (23), were treated with mesyl chloride to yield to polymer-bound mesylate (62) which, in the alkyne route, reacted with lithioacetylide to 
Scheme 10.

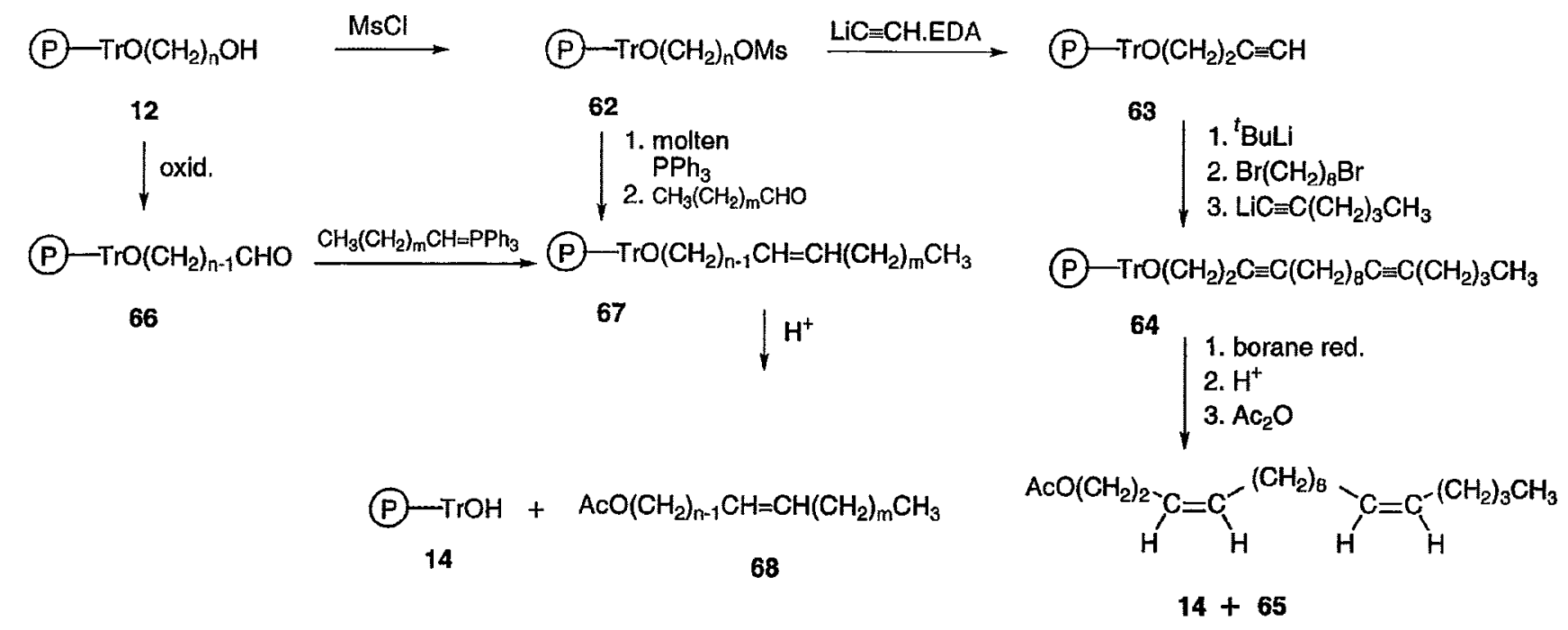

give the polymer-bound terminal alkyne $(63, n=2)$. Lithiation of 63 , followed by treatment with the symmetrical alkylating agent, 1,8-dibromooctane, gave the monoalkylated product, which was coupled with 1-lithio-1-hexyne to give the polymer-bound diyne (64). Although catalytic reduction of 64 with insoluble Pd or Pt catalysts was not possible, borane reduction proceeded even more easily than in solution as organoborane by-products were easily removed by simple filtration. Acid cleavage and acetylation readily gave $\mathbf{6 5}$, an insect sex attractant of the lesser peach borer, Synanthedon pictipes $(76,77)$ (Scheme 10). Alternatively, polymer 12 can be oxidized with di-tert-butyl chromate to give the polymer protected ether aldehyde 66 . Reaction of 66 with Wittig reagents, the Wittig route, give a variety of polymer-bound insect pheromones 67 , containing up to $33 \%$ of the $E$ isomer. On the other hand, in a "reverse" Wittig route, conversion of 62 with molten $\mathrm{PPh}_{3}$ gave a polymer bound Wittig reagent, which on treatment with aliphatic aldehydes again gave 67 ( $n=10, m=2$ ) with less than $9 \%$ of the $E$ isomer. Acid treatment and acetylation of 67 gave recovered polymer 14 and insect attractants (68) (78) (Scheme 10). It is notable, in the alkyne route, that the polymer-bound synthesis uses two steps to monoreact symmetrical disubstituted substrates and a borane reduction step to such an advantage that this sequence cannot be readily performed in solution. Natural insect pheromones often contain mixtures of $E, Z$ components so that the Wittig routes can be selected to give the desired mixture. The polymer support does affect the stereochemistry of the Wittig reactions (79). Large scale synthesis of pheromones using over $50 \mathrm{~g}$ of polymer supports and yielding up to $5 \mathrm{~g}$ of product have been reported (80). The synthesis of an insect pheromone using a polymerbound silyl chloride and a more convenient Moffatt-Swern oxidation is interesting (81) as is the recent related polymersupported Cadiot-Chodkiewicz coupling (82) giving conjugated unsymmetrical diynes, suitable for pheromones (82, 83).

One early example of a polymer-supported asymmetric synthesis (84) and high enantiomeric excesses (ee) achieved in solution (85) encouraged us to apply solid phases in asymmetric synthesis. Thus, Merrifield's polymer 69 reacted with the chiral blocked aminoalcohols 70 to give the polymer-bound chiral reagents 71 . Some unreacted chloro groups in 71 interfered with subsequent asymmetric synthesis, but these were converted to inactive methyl groups by treatment with NaI and reduction with tri- $n$-butyltin hydride. Deblocking with hydrazine gave the polymer-bound chiral reagents $\mathbf{7 2}$. Treatment of $\mathbf{7 2}$ with cyclohexanone gave polymer-bound chiral imine 73 which on alkylation and cleavage gave the valuable recovered polymer-bound chiral reagent 72 and $(S)$-2-methylcylohexanone (74)(86). Alternatively, in the first example of an asymmetric protonation (87) on polymer supports (88), addition of racemic 2-methylcyclohexanone to $\mathbf{7 2}$ gave $\mathbf{7 3}$ which on deprotonation and asymmetric protonation gave 74 (Scheme 11). The ee of 74 was comparable to that obtained using solution methods (85). As in polypeptide syntheses, partially reacted substrates on the polymer may be carried forward and interfere in a polymer-supported multi-step synthesis and awareness of this problem $(\mathbf{7 1} \rightarrow \mathbf{7 2})$ is a necessity.

Multi-step synthesis of cyclic compounds on solid phases became our next priority. Although a few Diels-Alder reactions had been performed on solid phases for mechanistic (89) or environmental purposes $(89 d)$, we wished to examine the effect of the polymer on regioselectivity in cycloaddition reactions (90). Thus, 69 reacted with acryloyl chloride to give polymer-bound acrylate (75), which on treatment with 1-phenyl-1,3-butadiene or methyl 2,4-pentadienoate gave the polymer-bound cyclohexenes $\mathbf{7 6}$ in good yield. Base cleavage and treatment with diazomethane gave a ratio of the ortho to meta Diels-Alders adducts 77 , similar to that achieved in solution, and hence the polymer support in this reaction did not affect the regiochemistry (Scheme 12). A polymer-bound chiral acrylate (78) was achieved by treatment of 69 with chiral 2-methyl-1,3-butanediol, esterification with acryloyl chloride, and blocking of unwanted primary alcohol groups with trityl chloride. Asymmetric Diels-Alder reactions of 78 using various titanium isopropoxy chlorides 
gave the polymer-bound chiral cyclohexenes 79. Reduction with $\mathrm{LiAlH}_{4}$ liberated the free chiral 3-cyclohexenylmethanols 80 plus recovered polymer 39 .

In this example the polymer-bound asymmetric synthesis also yielded product having a similar ee to that achieved in solution and hence the bulk of the polymer did not aid in giving higher ee's (91). Again note that side reactions encountered in going from $69 \rightarrow 78$ caused difficulties in this synthesis, but it was possible to take countervailing measures (Scheme 12).

Cycloaddition of 1,3-dipolarophiles on polymer supported alkynes gave simple heterocyclic compounds. Thus, 39 was treated with propiolic acid $(81 \mathrm{R}=\mathrm{H})$ or phenylpropiolic acid $(81 \mathrm{R}=\mathrm{Ph})$ with an acid catalyst to give the polymerbound alkynes 82 . The 1,3-dipolar addition (90) with benzonitrile $N$-oxide gave the polymer-bound isoxazoles 83 (from $82 \mathrm{R}=\mathrm{H}$ ) and 84 (from $82=\mathrm{Ph}$ ). Base cleavage of 83 and 84 and esterification with diazomethane gave the pure regioisomeric isoxazoles $\mathbf{8 5}$ and $\mathbf{8 6}$. The regioselectivity of 86 via the solid phase method was opposite to that observed in solution and hence, polymer-supported reactions can be different than their solution analogs $(92,93)$ (Scheme 13).

A report on the synthesis in very low yield of an unsymmetrical tetraarylporphyrin in solution (94) led us to examine the syntheses of heterocyclic macrocyclic compounds on polymer supports. Thus, polymer-bound acid chloride 54 was treated with $m$ - or $p$-hydroxybenzaldehyde $(87)$ to give the polymer-bound aldehydes $\mathbf{8 8}$. Treatment of $\mathbf{8 8}$ with pyrrole and excess tolualdehyde gave, after filtration from the excess symmetrical meso-tetratolylporphyrin produced, the unsymmetrical polymer-bound porphyrins 89. Cleavage of 89 with base gave in higher yield the unsymmetrical $m$ and $p$-hydroxyphenyl tritolylporphyrins 90 (95) (Scheme 14). This synthesis represents another example of the "fishhook" principle (47), whereby the minor desired component 89 on the polymer is fished out from the major symmetrical product in solution.

Pure unsymmetrical phthalocyanines were virtually unknown prior to 1980 and hence the polymer supported synthesis of porphyrins, described above, is eminently suited to be applied to the more complex heterocyclic macrocycles, the phthalocyanines (Pcs). For example, polymer-supported monotrityl hexanediol (12) underwent an aromatic nucleophilic displacement reaction with 4-nitrophthalonitrile and a phase transfer reagent in nitrobenzene to give the polymer-bound phthalonitrile (91). Conversion of 91 with base and $\mathrm{NH}_{3}$ gave the polymer-bound diiminoisoindoline (92). Treatment of 92 with a large excess of the isoindoline of 4-isopropoxyphthalonitrile gave the polymer-bound unsymmetrically substituted phthalocyanine $\mathbf{9 3}$ as the minor product and a large excess of the symmetrical phthalocyanine (Pc) (94). Again, simple filtration afforded pure 93 by the fishhook principle. Acid cleavage of 93 provided the first pure unsymmetrical Pc 95 (96) (Scheme 15). Other examples followed $(97,98)$.

Our early forays into the use of polymer-supports as monoblocking agents of symmetrical difunctional compounds led us to develop multi-step synthesis of linear compounds, such as insect pheromones and carotenoids, cyclic and heterocyclic compounds, such as cyclohexanes and isoxazoles, chiral compounds, and finally macrocyclic
Scheme 11.<smiles>C[C@H](CO)N1C(=O)c2ccccc2C1=O</smiles><smiles>C[C@H](COCc1ccccc1)N1C(=O)c2ccccc2C1=O</smiles><smiles>N[C@H](CP)COCc1ccccc1</smiles><smiles>[R]C1CCCCC1=N[C@@H](C)[C@H](C)COCc1ccccc1</smiles>

$$
73 \mathrm{R}=\mathrm{H}, \mathrm{Ph}, \mathrm{R}^{\prime}=\mathrm{H}, \mathrm{CH}_{3}
$$

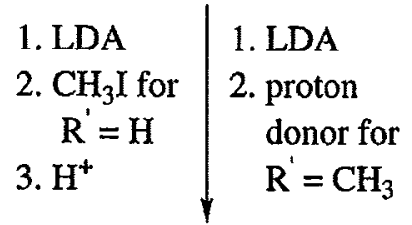<smiles>C[C@H]1CCCCC1=O</smiles> 
Scheme 12.

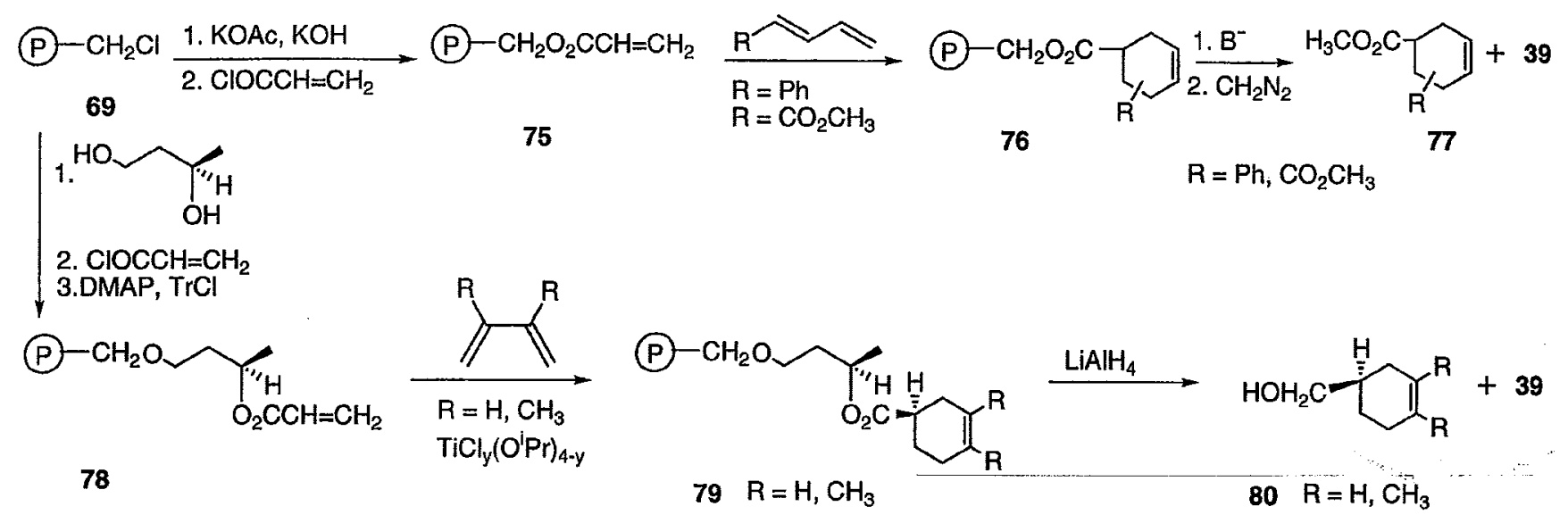

Scheme 13.

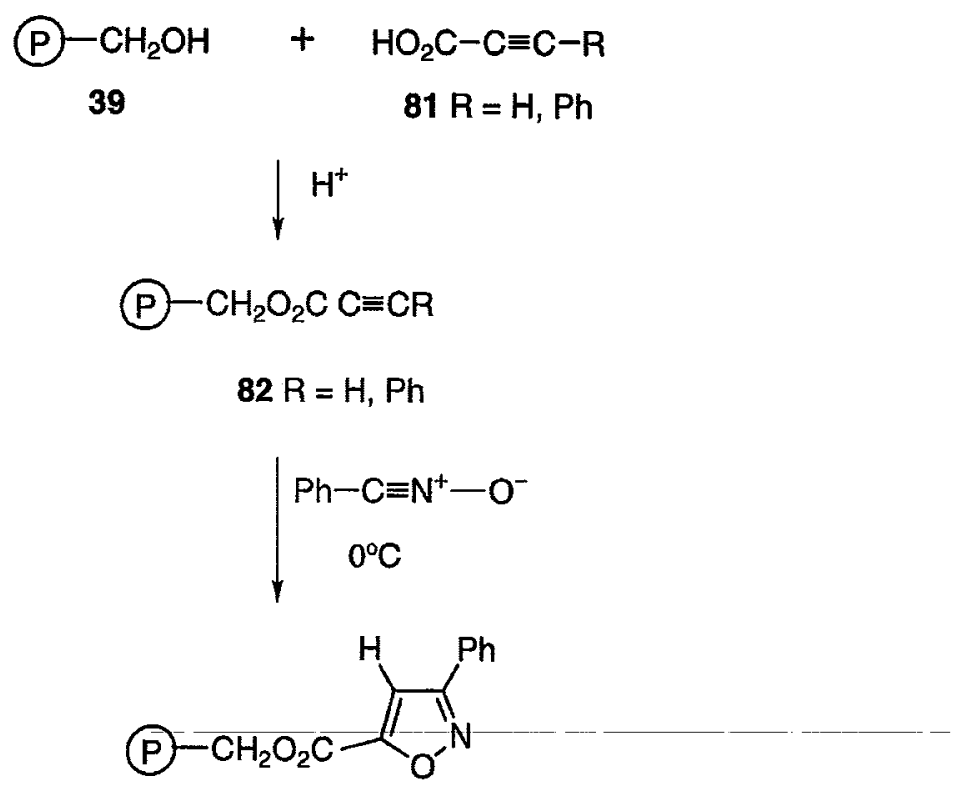

83 from $\mathrm{R}=\mathrm{H}$<smiles></smiles><smiles>[3H]Cc1c(-c2ccccc2)noc1C(=O)OC</smiles> 
Scheme 14.

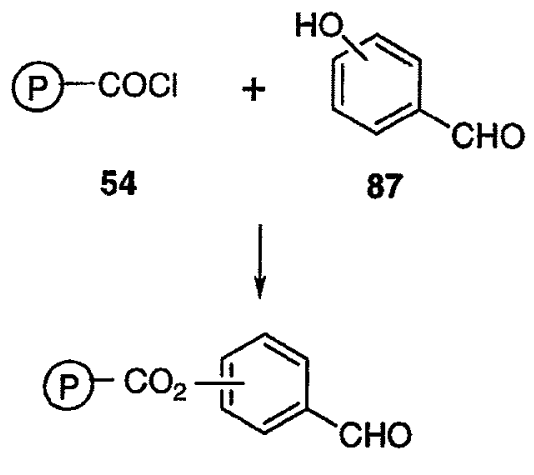

88

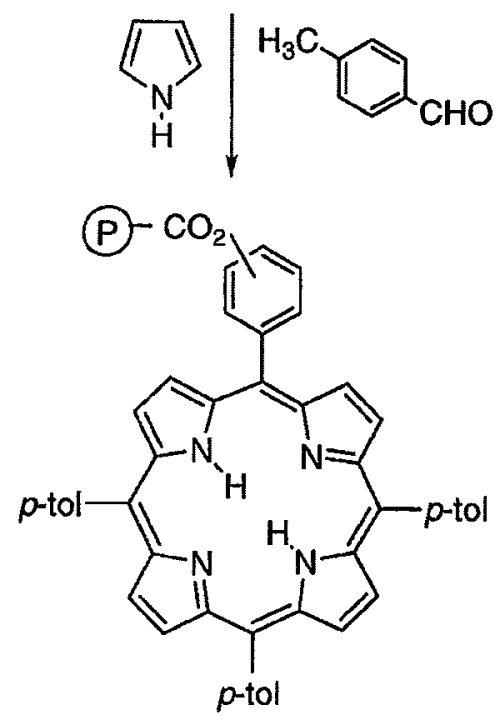

89

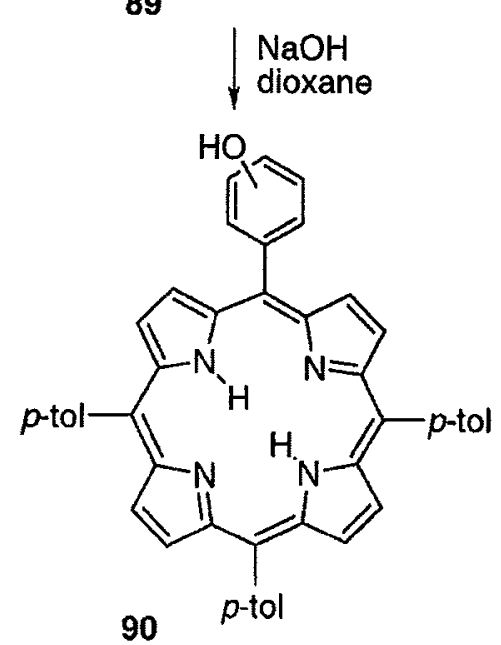

Scheme 15.

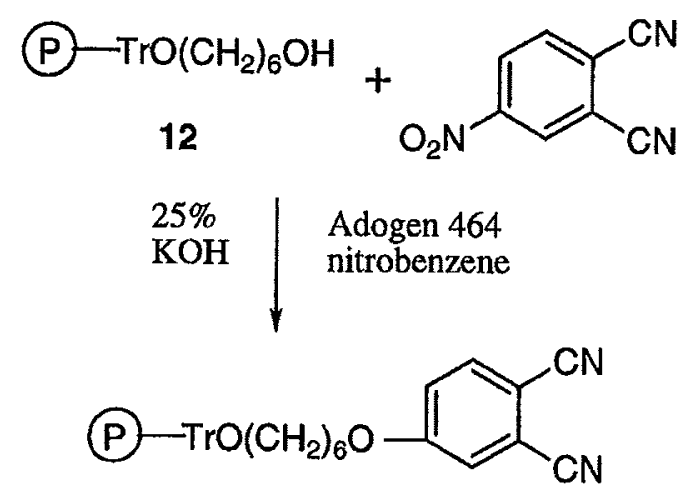

91

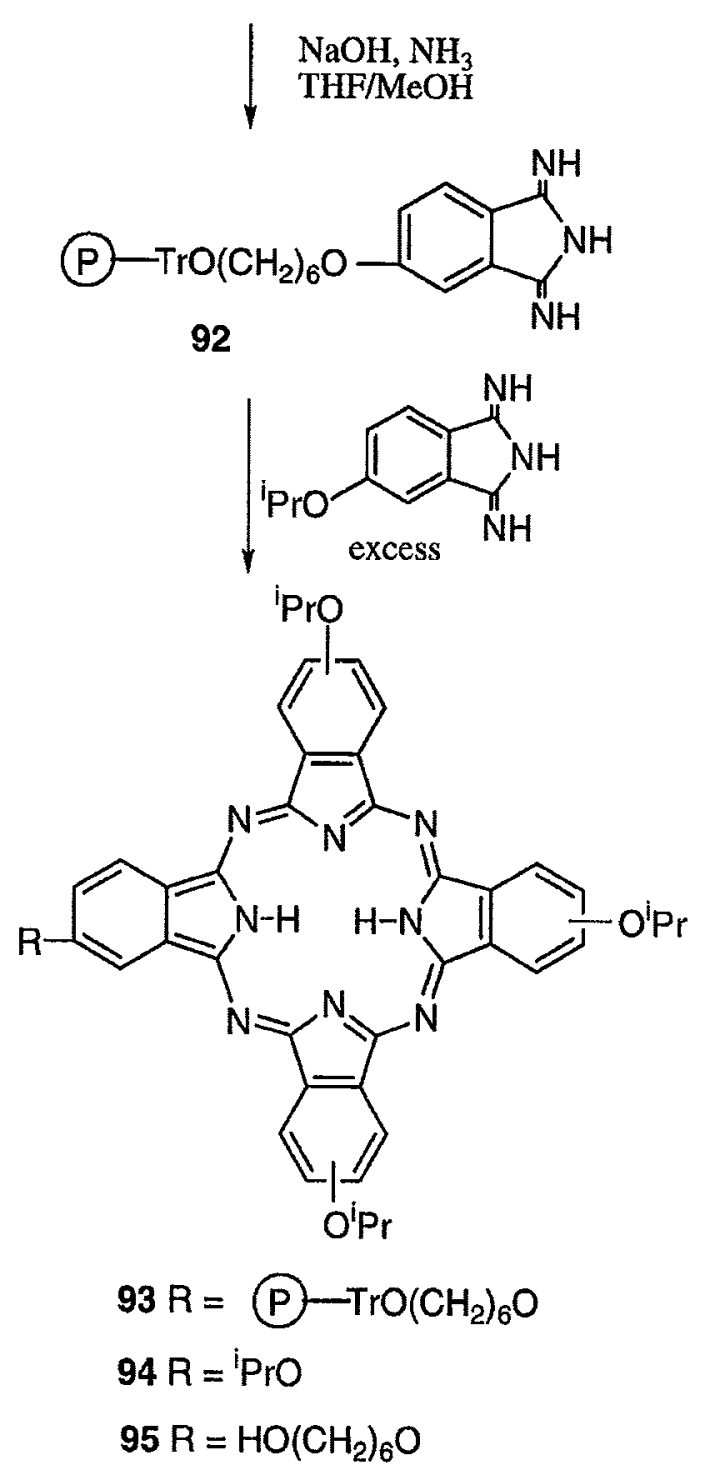


Scheme 16.<smiles>CCC(C)(CO)CO</smiles><smiles>CCC(C)(COc1ccc(C#N)c(C#N)c1)COc1ccc(C#N)c(C#N)c1</smiles>

97

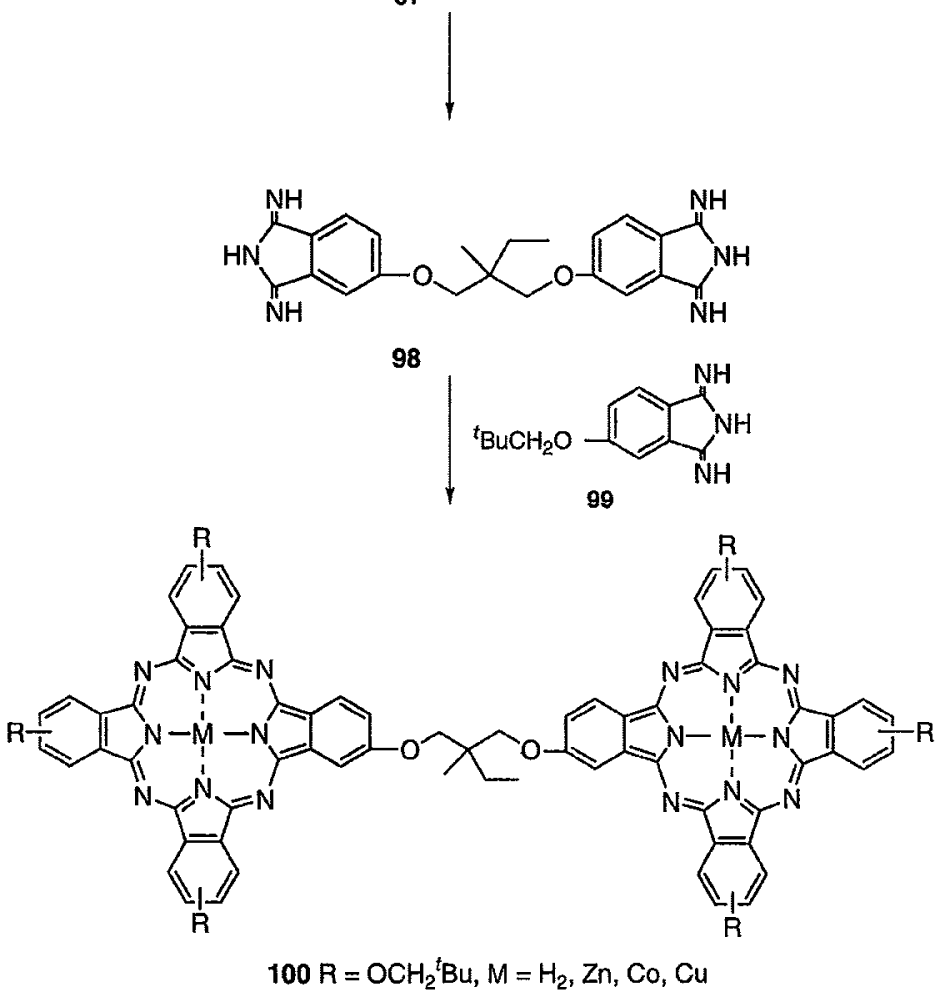

compounds such as porphyrins and phthalocyanines. Perhaps most importantly, it was demonstrated that a wide variety of common organic reactions could be performed readily on solid phases. These included ether and ester formation, Wittig and organometallic reactions, aldol condensations, oximation, amide formation, borane, borohydride and tin hydride reductions, non-chiral and chiral alkylations, mesylations, alkyne couplings, oxidations, Diels-Alder and 1,3-dipolar additions, and finally Rothemund type $(99,100)$ prophyrin and Linstead (101) phthalocyanine macrocyclic formations. Some more recent reactions that are noteworthy include the "traceless" attachment of substrates to polymer supports $(102,103)$, the four component Ugi reaction (104), the Pauson-Khand reaction (105), soluble palladium coupling reactions (106), and other protocols on solid phases (107). Other reactions are outlined in a number of early (47-49) and more recent reviews on SPOS $(108,109)$ and in reviews on the applications of polymer-supported synthesis in combinatorial chemistry $(71-73,109)$.

\section{Phthalocyanines}

Our synthesis of the first characterized unsymmetrically substituted Pc (96) whetted our appetite for further studies in phthalocyanine chemistry (110-113). During this time, it was shown that certain bridged binuclear porphyrins (114116) were able to act as catalysts in the 4e-reduction of $\mathrm{H}_{2} \mathrm{O}$ to hydrogen and oxygen, although the catalysts tended to decompose with time. Since it was known that Pcs are very much more robust than porphyrins and Pcs can even be used as paint coatings for automotibles, we embarked on a program to make hitherto unknown bridged binuclear phthalocyanines and study their electrocatalytic properties. To 
Scheme 17.
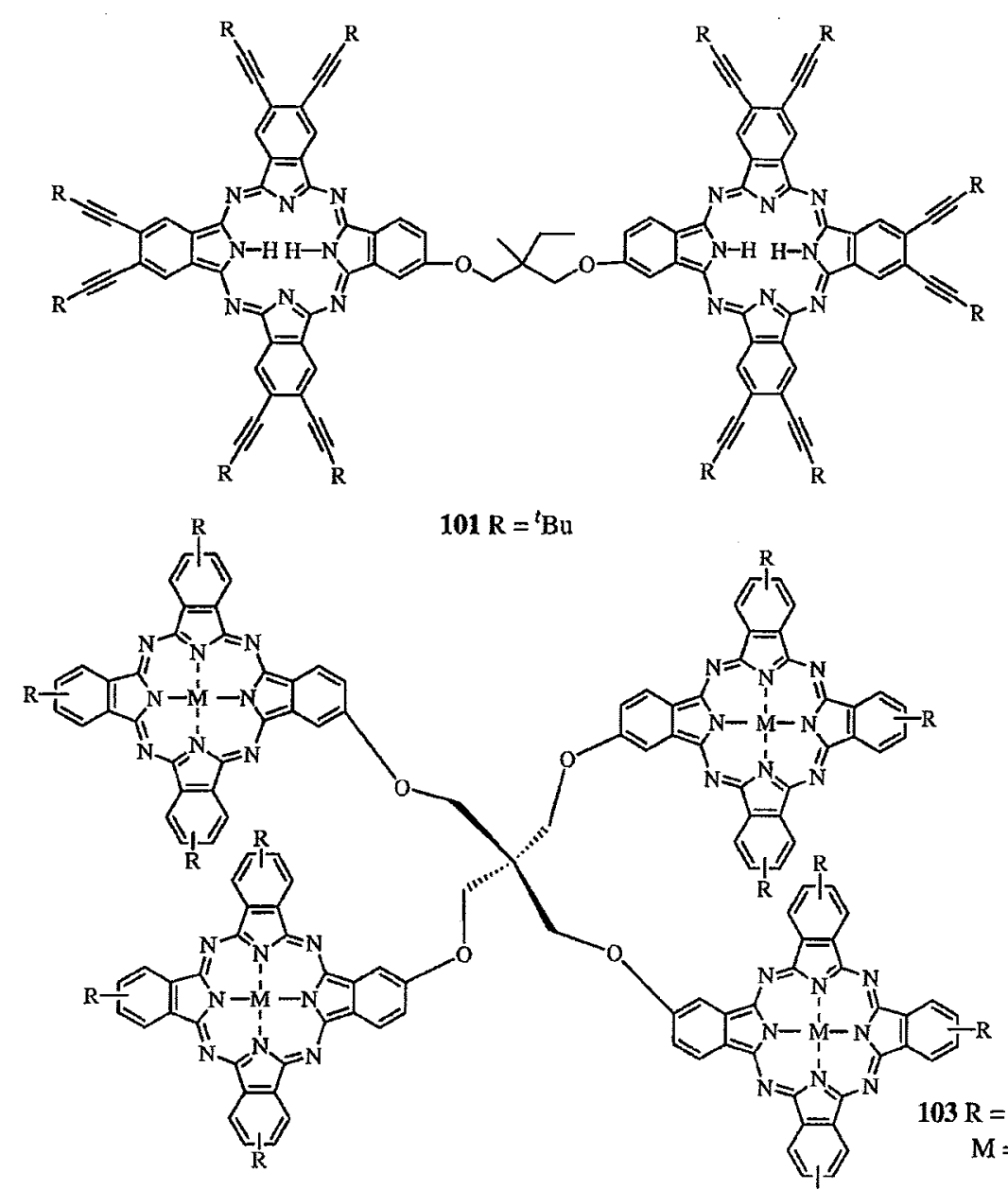

$\mathrm{R}={ }^{t} \mathrm{Bu}$
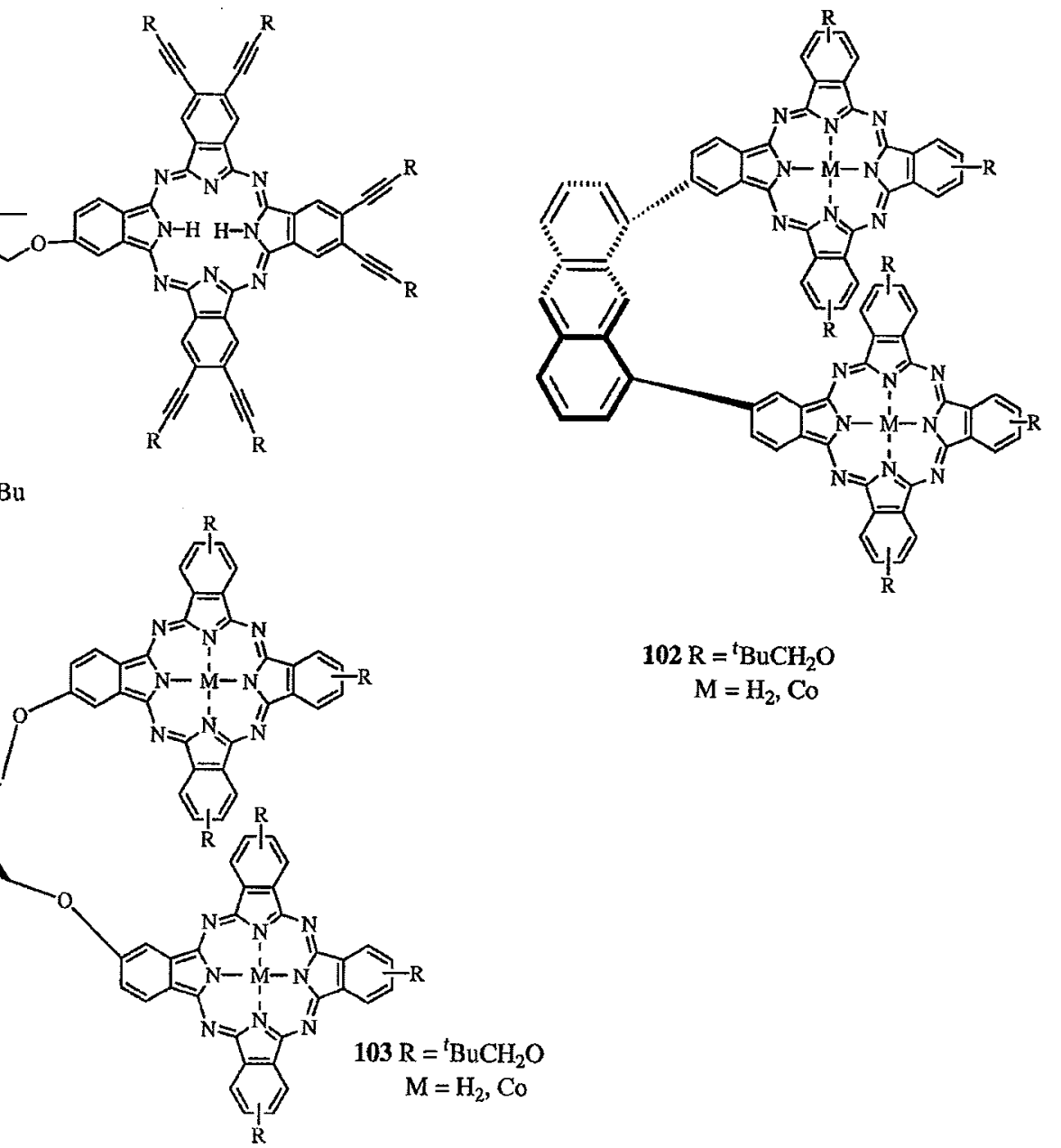

$102 \mathrm{R}={ }^{t} \mathrm{BuCH}_{2} \mathrm{O}$

$\mathrm{M}=\mathrm{H}_{2}, \mathrm{Co}$

solubilize the rather insoluble pthhalocyanines, we used the bulky neopentoxy (2,2-dimethyl-1-propoxy) group as a solubilizing substituent. Since bridged binuclear Pcs are essentially unsymmetrical Pcs in which one substituent is simply another Pc group, our prior experience in synthesizing an unsymmetrical Pc on a polymer support served us well. Thus, treatment of 2-ethyl-2-methyl-1,3-propanediol (96) with base and 4-nitrophthalonitrile gave the bisphthalonitrile (97). Conversion of 97 to its bisdiiminoisoindoline (98) as before, followed by condensation with a large excess of the diiminoisoindoline (99) of 4-neopentoxyphthalonitrile, resulted in a mixture of a large amount of mononuclear 2,9,16,23-tetraneopentoxyphthalocyanine and some binuclear phthalocyanines (100) as a metal-free derivative into which various metals could be inserted $(117,118)$. Amusingly, gel permeation chromatography $(94,118)$, using the same $2 \%$ cross-linked polystyrene used in SPOS, was crucial in separating the mono- and binuclear $P c s$ in a final purification step (Scheme 16) in this and other polynuclear phthalocyanines (119-122). The method of synthesis of 100 gives the binuclear Pcs as a mixture of regioisomers which is actu- ally beneficial as this mixture helps promote the solubility of 100. More recently, we substituted the tert-butylalkynyl group for the neopentoxy group and we were able to make a binuclear Pc as the pure single isomer 101 (123) (Scheme 17).

Other rigid bridged binuclear Pcs based on attachment of Pcs to the 1,8-positions of anthracene (102) (124), naphthalene (125), and phenanthrene (126) were also synthesized (Scheme 17). Trinuclear (121), tetranuclear 103 (127) (Scheme 17), and even a dendriditic-like pentanuclear phthalocyanine (104) (128) succumbed to the synthetic anvil (Scheme 18). Cyclic voltammetry $(128,129)$ and LangmuirBlodgett studies (130) of the polynuclear phthalocyanines yielded many insights on intraphthalocyanine interactions (128) including step by step oxidation-reductions of the Pcs rings. However, in all cases, the two electron reduction of $\mathrm{O}_{2}$ to $\mathrm{H}_{2} \mathrm{O}_{2}$ was observed (most efficiently with tetranuclear $\mathrm{Pc}$ 104).

Currently, we are interested in preparing polyalkynyl phthalocyanines $(122 b, 123,131-33)$ for use in nonlinear optics (134) and in shifting the absorption maxima of Pcs towards longer wavelengths. To this end, the $2,3,9,10,16$, 


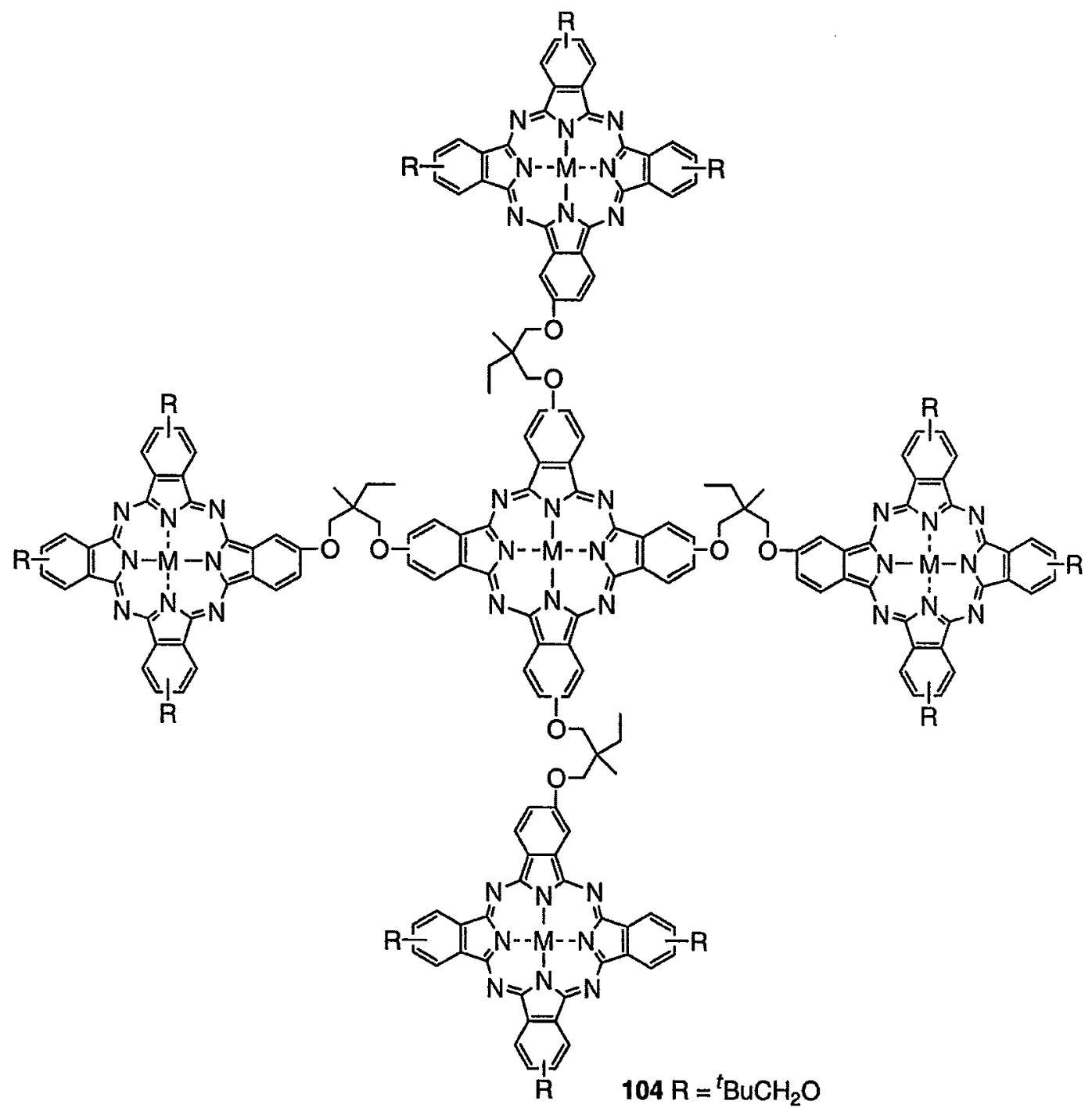

17,23,24-octaphenylethynylphthalocyanines $\mathbf{1 0 5}$ and $\mathbf{1 0 6}$ have been prepared. Phthalocyanine $\mathbf{1 0 5}$ is extremely insoluble, but again, the neopentoxy groups in $\mathbf{1 0 6}$ provide this very planar Pc with enough bulkiness to prevent aggregation and enhance solubility. The polyoctabutadiynyl Pc 107, although soluble, is fairly unstable and decomposes slowly (135).

\section{Conclusions}

In the 1970's, SPOS was considered as unusual and impractical, but through the advent of combinatorial chemistry, has become an important endeavour in the 1990's. I have shown how our curiosity-driven research later came to have important practical considerations, and led us to develop a new interest in phthalocyanine chemistry, the applications of which are only now beginning to be realized.

\section{Acknowledgement}

I would like to thank the many outstanding graduate students, postdoctoral fellows, research associates, and collabo- rators at York, as well as those at other institutions who have made this work possible and indeed enjoyable and whose names appear in the references quoted. We thank the Natural Sciences and Engineering Research Council of Canada for major support through operating, strategic, and collaborative grants. Other agencies supporting this research included the Petroleum Research Fund, the Ontario Ministry of the Environment, and the Office of Naval Research (U.S.A.).

\section{References}

1. R.B. Merrifield. J. Am. Chem. Soc. 85, 2149 (1963),

2. R.L. Letsinger and M.J. Kornet. J. Am. Chem. Soc. 85, 3045 (1963).

3. R.B. Merrifield. Science (Washington, D.C.), 150, 178 (1965).

4. (a). R.L. Letsinger and V. Mahadevan. J. Am. Chem. Soc. 87, 3526 (1965); (b) R.L. Letsinger and V. Mahadevan. J. Am. Chem. Soc. 88, 5319 (1966).

5. (a) F. Cramer and H. Koster. Angew. Chem. Int. Ed. Engl. 7, 473 (1968); (b) H. Koster. Tetrahedron Lett. 13, 1527 (1972). 


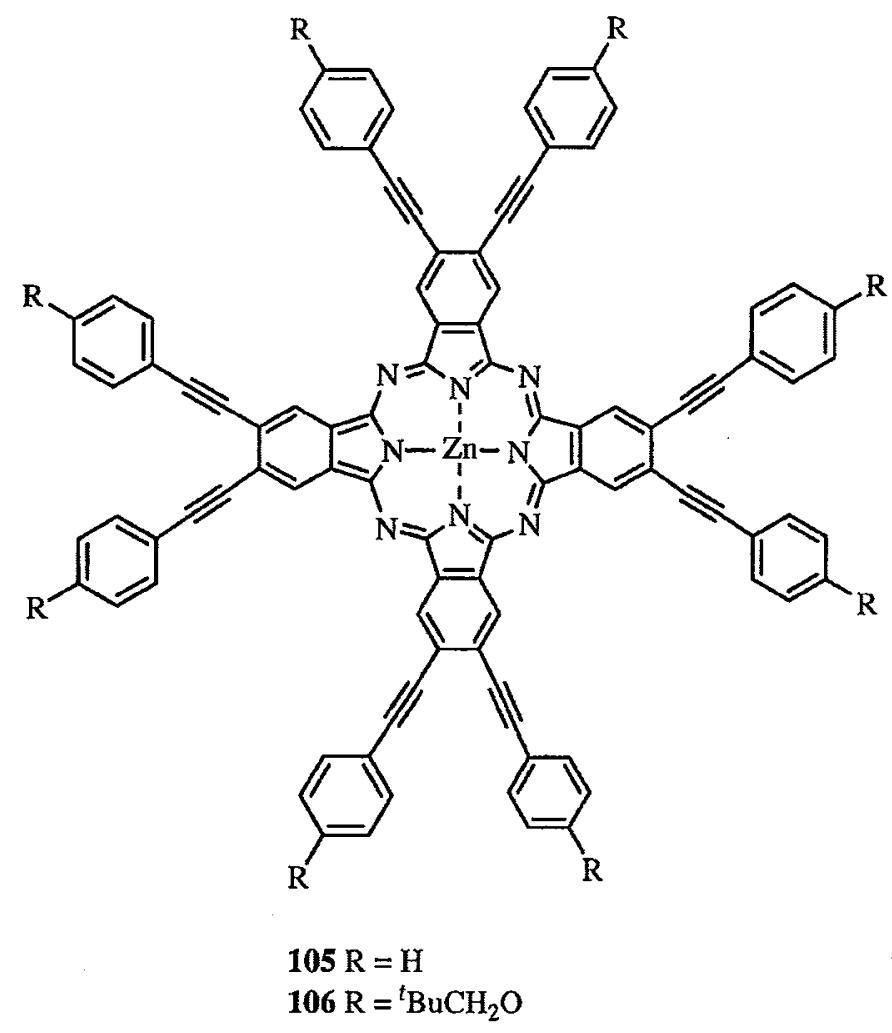

6. (a) M.J. Gait and R.C. Sheppard. J. Am. Chem. Soc. 98, 8514 (1976); (b) S.L. Beaucage and R.P. Iyer. Tetrahedron, 48, 2223 (1992).

7. (a) J.M.J. Fréchet and C. Schuerch. J. Am. Chem. Soc. 93, 492 (1971); (b) S.P. Douglas, D.M. Whitfield, and J.J. Krepinsky. J. Am. Chem. Soc. 113, 5095 (1991); (c) S.J. Danishefsky, K.F. McClure, J.J. Randolph, and R.B. Ruggeri. Science (Washington, D.C.), 260, 1307 (1993).

8. (a) G.B. Fields and R.L. Noble. Int. J. Pept. Protein Res. 35. 161 (1990); (b) M.R. Pavia, T.K. Sawyer, and W.H. Moos. Bioorg. Med. Chem. Lett. 3, 387 (1993).

9. (a) F.X. Montserra, A. Grandas, R. Eritja, and E. Pendroso. Tetrahedron, 50, 2617 (1994).

10. (a). V. Amarnath and A.D. Broom. Chem. Rev. 77, 183 (1977); (b) P.H. Seeberger and S.J. Danishefsky. Acc. Chem. Res. 31, 685 (1998); (c) H.M.I. Osborn and T.H. Kwan. Tetrahedron, 55, 1807 (1999).

11. (a) R.B. Merrifield, J.M. Stewart, and N. Jernberg. Anal. Chem. 38, 1905 (1966); (b) B. Gutte and R.B. Merrifield. J. Am. Chem. Soc. 91, 501 (1969); (c) J.M. Stewart and J.D. Young. Solid Phase Peptide Synthesis. W.H. Freeman, San Francisco. 1969; (d) E. Wunsch. Angew. Chem. Int. Ed. Engl. 10. $786(1971)$.

12. R.N. Zuckerman, J.M. Kerr, M.A. Siani, and S. Banville. Int. J. Pept. Protein Res. 40, 497 (1992).

13. (a) G. Jung and A.G. Beck-Sickinger. Angew. Chem. Int. Ed. Engl. 31, 367 (1992); (b) G.M. Gait. Solid phase oligonucleotide synthesis: a practical approach. IRL, Oxford. 1992.

14. M. Fridkin, A. Patchornik, and E. Katchalsky. J. Am. Chem. Soc. 88, 3164 (1966).

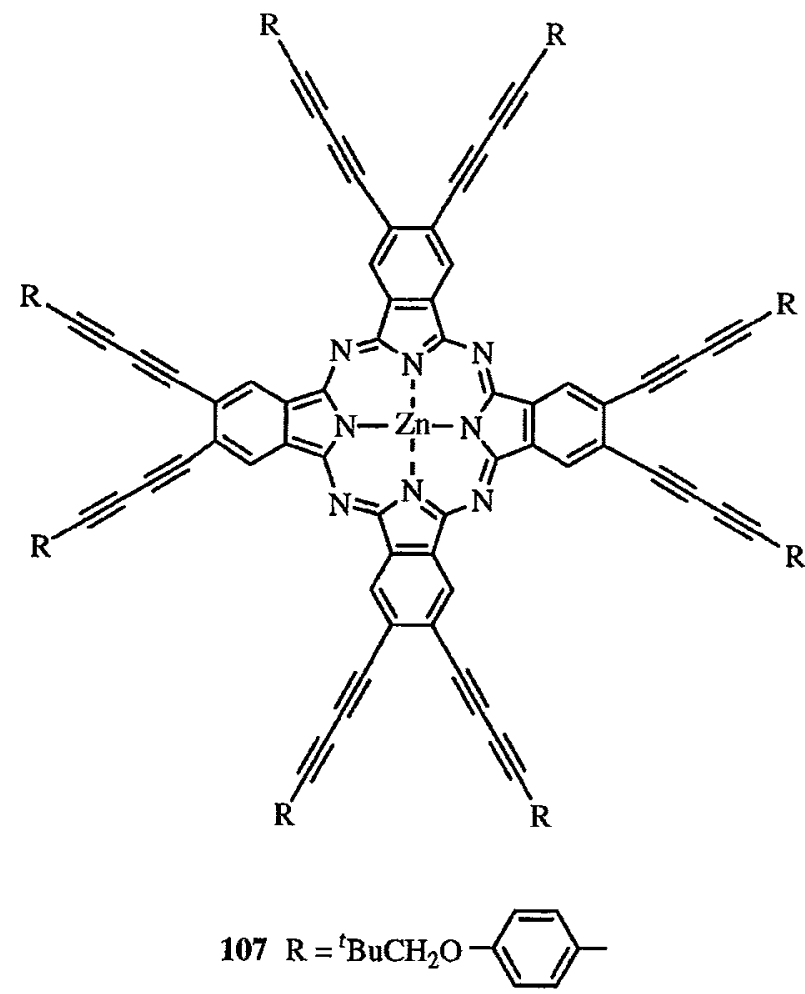

15. A. Patchornik and M.A. Kraus. Pure Appl. Chem. 43, 503 (1975).

16. (a) N.K. Mathur, C.K. Narang, and R.E. Williams. Polymer as aids in organic chemistry. Academic Press, New York. 1980; (b) P. Hodge. In Polymer supported reactions. Edited by P. Hodge and D.C. Sherrington. Wiley, New York. 1980. pp. 83-155. (c) J.M.J. Fréchet. Tetrahedron, 37, 663 (1981); (d) W. Heitz. Adv. Polym. Sci. 23, 2 (1977).

17. (a) D.C. Neckers, D.A. Kooistra, and G.W. Green. J. Am. Chem. Soc. 94, 9284 (1972); (b) S.J. Shuttleworth, S.M. Allin, and P.K. Sharma. Synthesis, 1217, (1997).

18. Y. Gaoni, C.C. Leznoff, and F. Sondheimer. J. Am. Chem. Soc. 90, 4940 (1968).

19. I.T. Harrison and S. Harrison. J. Am. Chem. Soc. 89, 5723 (1967).

20. T. Kusama and H. Hayatsu. Chem. Pharm. Bull. 18, 319 (1970).

21. C. C. Leznoff and J.Y. Wong. Can. J. Chem. 50, 2892 (1972).

22. J.Y. Wong and C.C. Leznoff. Can. J. Chem. 51, 2452 (1972).

23. T.M. Fyles and C.C. Leznoff. Can. J. Chem. 54, 935 (1976).

24. J.M.J. Fréchet and L.J. Nuyens. Can. J. Chem. 54, 926 (1976).

25. C.C. Leznoff and J.Y. Wong. Can. J. Chem. 51, 3756 (1973).

26. J.Y. Wong, C. Manning, and C.C. Leznoff. Angew. Chem. Int. Ed. Engl. 13, 666 (1974).

27. J.M. Vanest, M. Gorsane, V. Libert, J. Pecher, and R.H. Martin. Chimia, 29, 343 (1975).

28. C.C. Leznoff and W. Sywanyk. J. Org. Chem. 42, 3203 (1977).

29. Z.-H. Xu and H. Cheng. Huaxue Tongbao, 14 (1985); Chem. Abstr. 103, 105384b (1985).

30. Z.-H. Xu, C.R. McArthur, and C.C. Leznoff. Can. J. Chem. 61, 1405 (1983). 
31. C.C. Leznoff and Z.-H. Xu. Huaxue Tongbao, 16 (1983); Chem. Abstr. 99, 194503d (1983).

32. S. Chamoin, S. Houldsworth, C.G. Kruse, W.I. Bakker, and V. Snieckus. Tetrahedron Lett. 39, 4179 (1998).

33. (a) C.C. Leznoff and S. Greenberg. Can. J. Chem. 54, 3824 (1976); (b) C. Bied-Charreton, J.P. Idoux, and A. Gaudemar. Nouv. J. Chim. 2, 303 (1978); (c) P. Hodge and J. Waterhouse. J. Chem. Soc. Perkin Trans 1, 2319 (1983); (d) Q. Ren, W. Huang, and B. He. Huaxue Xuebao, 47, 827 (1989); Chem. Abstr. 112, 56903v (1990); (e) S. Chandrasekhan and M.B. Padmaja. Synth. Commun. 28, 3715 (1998); $(f) \mathrm{J}$. Chen and R. Xiao. Gaofenzi Tongxun, 467 (1986); Chem. Abstr. 106, 214796v (1987).

34. S. Hanessian and H.K. Huynh. Synlett, 102, (1999).

35. (a) J.M.J. Fréchet and E. Seymour. Isr. J. Chem. 17, 253 (1978); (b) J.M.J. Fréchet, L.J. Nuyens, and E. Seymour. J. Am. Chem. Soc. 101, 433 (1979).

36. (a) D.M. Dixit and C.C. Leznoff. J. Chem. Soc. Chem. Commun. 798 (1977); (b) D.M. Dixit and C.C. Leznoff. Isr. J. Chem. 17, 248 (1978).

37. (a) H. Boulen, B. Martens, and D. Wöhrle. Makromol. Chem. Rapid Comm. 1, 753 (1980); (b) B.A. Dressman, L.A. Spangle, and S.W. Kaldor. Tetrahedron Lett. 37, 937 (1996); (c) J.J. McNally, M.A. Youngman, and S. L. Dax. Tetrahedron Lett. 39, 967 (1998).

38. C.C. Leznoff and J.M. Goldwasser. Tetrahedron Lett. 18, 1875 (1977).

39. J.M. Goldwasser and C.C. Leznoff. Can. J. Chem. 19, 1562 (1978).

40. G. Cahiez and J.F. Normant. Tetrahedron Lett. 18, 3383 (1977).

41. C.C. Leznoff and V. Yedidia. Can. J. Chem. 58, 287 (1980).

42. J.W. Apsimon and D.M. Dixit. Synth. Commun. 12, 113 (1982).

43. B.C. Hamper, S.A. Kolodziej, and A.M. Scates. Tetrahedron Lett. 39, 2047 (1998).

44. (a) G. Bhalay, P. Blaney, V.N. Palmer, and A.D. Baxter. Tetrahedron Lett. 38, 8375 (1997); (b) A. Wahhab and J. Leban. Tetrahedron Lett. 40, 235 (1979).

45. F. Gaviña, A.M. Costero, P. Gil, B. Palazon, and S.V. Luis. J. Am. Chem. Soc. 103, 1797 (1981).

46. F. Gaviña, A.M. Costero, and S.V. Luis. J. Org. Chem. 49, 4617 (1984).

47. (a) C.C. Leznoff. Chem. Soc. Rev. 3, 65 (1974); (b) C.C. Leznoff. Acc. Chem. Res. 11, 327 (1978).

48. (a) J.I. Crowley and H. Rapoport. Acc. Chem. Res. 9, 135 (1976); (b) J. Rebek, Jr. Tetrahedron, 35, 723 (1979); (c) A. Akelah and D.C. Sherrington. Chem. Rev. 81, 557 (1981); (d) J.M.J. Fréchet. Tetrahedron, 37, 663 (1981).

49. (a) J.S. Früchtel and G. Jung. Agnew. Chem. Int. Ed. Engl. 35, 17 (1996); (b) I.W. James. Tetrahedron, 55, 4855 (1999).

50. C.C. Leznoff and D.M. Dixit. Can. J. Chem. 55, 3351 (1977).

51. T.M. Fyles, C.C. Leznoff, and J. Weatherston. Can. J. Chem. 56, 1031 (1978).

52. (a) B. Castro, M. Ly, and C. Selve. Tetrahedron Lett. 14, 4455 (1973); (b) J.H. Babler and M.J. Coghlan. Tetrahedron Lett. 20, 1971 (1979); (c) S. David and A. Thieffry. J. Org. Chem. 48, 441 (1983); (d) S.B. Fergusson and H. Alper. J. Chem. Soc. Chem. Commun. 1349 (1984); (e) P.G. McDougal, J.G. Rico, Y.-Im. On, and B.D. Condon. J. Org. Chem. 51, 3389 (1986); (f) S.K. Kang, W.-S. Kim, and B.H. Moon. Synthesis, 1161 (1985); (g) F. Camps, J.M. Casamor, J. Coll, A. Guerrero, and M. Riba. Org. Prep. Proced. Int. 15, 63 (1983).

53. (a) T. Nishiguchi and H. Taya. J. Am. Chem. Soc. 111, 9102 (1989); (b) T. Nishiguchi. J. Org. Chem. 59, 1191 (1994); (c) T. Nishiguchi, K. Kawamine, and T. Ohtsuka. J. Chem. Soc. Perkin
Trans. 1, 153 (1992); (d) T. Nishiguchi, M. Kuroda, M. Saitoh, A. Nishida, and S. Fujisaki. J. Chem. Soc. Chem. Commun. 2491 (1995); (e). T. Nishiguchi, S. Fujisaki, M. Kuroda, K. Kajisaki, and M.Satoh. J. Org. Chem. 63, 8183 (1998).

54. (a) V.E.M. Kaats-Richters, J.W. Zwikker, E.M.D. Keegstra, and L.W. Jenneskens. Synth. Commun. 24, 2399 (1994); (b) D. Komiotis, B.L. Currie, G.C. LeBreton, and D.L. Venton. Synth. Commun. 23, 531 (1993); (c) A. Ndibwami, S. Lamothe, D. Guay, R. Plante, P. Soucy, S. Goldstein, and P. Deslongchamps. Can. J. Chem. 71, 695 (1993); (d) F. Freeman, D.S.H.L. Kim, and E. Rodriguez. J. Org. Chem. 57, 1722 (1992); (e) J. Otera, N. Dan-Oh, and H. Nozaki. J. Chem. Soc. Chem. Commun. 1742, (1991); (f) U.P. Dhokte, V.V. Khau, D.R. Hutchison, and M.J. Martinelli. Tetrahedron Lett. 39, 8771 (1998); $(g)$ H. Ogawa, M. Amano, and T. Chihara. J. Chem. Soc. Chem. Commun. 495 (1998); $(h)$ D. Wong and C.-J. Li. Synth. Commun. 28, 507 (1998).

55. O. Hoville, T. Schmittberger, and D.D. Uguen. Tetrahedron Lett. 37, 625 (1996).

56. (a) N.G. Lukyanenko and O.T. Melnik. Zh. Org. Khim. 24, 2227 (1988); (b) G.D. Gamalevich, B.N. Morozov, A.L. Vlazyuk, and E.P. Serebryakov. Tetrahedron, 55, 3665 (1999).

57. (a) K. Hollmann and M. Ecke. Z. Chem. 29, 63 (1989); (b) M. Hayashi, K. Hiratani, S.-I. Kina, M. Ishii, and K. Saigo. Tetrahedron Lett. 39, 6211 (1998); (c) J.R. Hwu, W.N. Tseng, J. Ghabre, P. Giza, and R.C.C. Huang. J. Med. Chem. 41, 2994 (1998).

58. (a) R. Crux-Almanza, E.G. Pérez-Flores, and M. Avila. Synth. Commun. 20, 1125 (1990); (b) D. Johnston. Chem. Ind. London, 1000 (1982); (c) J.E. Otis, Jr., T. Walle, H.B. Daniell, T.E. Gaffney, and D.R. Knapp. J. Med. Chem. 28, 822 (1985).

59. (a) B.O. Brown and B.C.L. Weedon. Finn. Chem. Lett. 102 (1984); (b) C. Botteghi and F. Soccolini. Synthesis, 592 (1985).

60. (a) G.D. Hartman, B.T. Phillips, and W. Halczenko. J. Org. Chem. 50, 2423 (1985); (b) G. Smith and G. Kruger. J. Org. Chem. 50, 5759 (1985); (c) S. Michaud and J. Viala. Tetrahedron, 55, 3019 (1999); (d) L.F. Tietze, H. Meier, and E. Voss. Synthesis, 274 (1988); (e) J. Hiratake, K. Shibata, N. Baba, and J. Oda. Synthesis, 278 (1988).

61. (a) T. Cuvigny, M. Larcheveque, and H. Normant. Synthesis, 857 (1978); (b) T. Volpe, G. Revial, M. Peau, and J. d'Angelo. Tetrahedron Lett. 27, 2853 (1986); (c) M. C. Pirrung and D.S. Nunn. Tetrahedron Lett. 33, 6591 (1992).

62. C.M. Hall and J.B. Wright. U.S. Patent 4, 128, 660 (1978); Chem. Abstr. 90, 103668m (1979).

63. (a) G.L. Stahl, R. Walter, and C.W. Smith. J. Org. Chem. 43, 2285 (1978); (b) M.M. Ponpipom. Carbohydr. Res. 113, 45 (1983); (c) R. Houssin, J.-L. Bernier, and J.-P. Hénichart. Synthesis, 259 (1988); (d) K. Kaljuste and A. Unden. Tetrahedron Lett. 36, 9211 (1995). (e) S.M. Hutchins and K.T. Chapman. Tetrahedron Lett. 36, 2583 (1995). (f) G.J. Atwell and W.A. Denny. Synthesis, 1032 (1984).

64. W.C. Chou, M.-C. Chou, Y.-Y. Lu, and S.-F. Chen. Tetrahedron Lett. 40, 3419 (1999)

65. J. Otera, N. Dan-Oh, and H. Nozaki. Tetrahedron, 49, 3065 (1993).

66. (a) T.R. Hoye and N.E. Witowski. J. Am. Chem. Soc. 114, 7291 (1992). (b) M. Lobell and M.P. Schneider. J. Chem. Soc. Perkin Trans. 1, 1713 (1993).

67. F.V. Brutcher, Jr. and H. Hinney. Tetrahedron Lett. 20, 679 (1979).

68. H. Ogawa, T. Chihara, and K. Taya. J. Am. Chem. Soc. 107, 1365 (1985). 
69. C. Rogers and B.P. Keay. Can. J. Chem. 70, 2929 (1992).

70. (a) R. Kikumoto, A. Tobe, H. Fukami, K. Ninomiya, and M Egawa. J. Med. Chem. 27, 645 (1984); (b) G.D. Diana, M.A. McKinlay, C.J. Brisson, F.S. Zalay, J.V. Miralles, and U.J. Salvador. J. Med. Chem. 28, 748 (1985); (c) G.A. Kraus and K. Landgrebe. Synthesis, 885 (1984).

71. (a) H.M. Geysen, R.H. Melden, and S.J. Barteling. Proc, Nat. Acad. Sci. U.S.A. 81, 3998 (1984); (b) R.A. Houghten. Proc. Nat. Acad. Sci. U.S.A. 82, 5131 (1985); (c) A. Furka, F. Sebestyen, M. Asgedom, and G. Dibo. Int. J. Pept. Protein Res. 37, 487 (1991); (d) K. Lam, S. Salmon, E. Hersh, V. Hruby, W. Kazmierski, and R. Knapp. Nature (London), 354, 82 (1991); (e) S.H. DeWitt, J.S. Kiely, C.J. Stankovic, M.C. Schroeder, D.M.R. Cody, and M.R. Pavia. Proc. Nat. Acad. Sci. U.S.A. 90, 6909 (1993).

72. (a) E.M. Gordon, R.W. Barrett, W.I. Dower, S.P.A. Fodor, and M.A. Gallop. J. Med. Chem. 37, 1385 (1994); (b) F. Balkenhohl, C. von dem Bussche-Hünnefeld, A. Lansky, and C. Zechel. Angew. Chem. Int. Ed. Engl, 35, 2288 (1996).

73. (a) A. Nefzi, J.R. Ostrech, and R.A. Houghton. Chem. Rev. 97, 449 (1997); (b) J.A. Ellman. Acc. Chem. Res. 29, 132 (1996); (c) S.H. DeWitt and A. Czarnik. Acc. Chem. Res. 29, 114 (1996)

74. C.C. Leznoff and T.M. Fyles. J. Chem. Soc. Chem. Commun. 251 (1976).

75. C.C. Leznoff, T.M. Fyles, and J. Weatherston. Can. J. Chem. 55, 1143 (1977).

76. P.I. Svirskaya and C.C. Leznoff. J. Chem. Ecol. 10, 321 (1984).

77. C.C. Leznoff. In Biotechnology: applications and research. Edited by P.N. Cheremisinoff and R.P. Ouellette. Technomic Pub1. Co., Lancaster, Penn. 1985. pp. 586-593.

78. T.M. Fyles, C.C. Leznoff, and J. Weatherston. Can. J. Chem. 56, 1031 (1978).

79. (a). T.M. Fyles, C.C. Leznoff, and J. Weatherston. Can. J. Chem. 55, 4135 (1977); (b) T.M. Fyles, C.C. Leznoff, and J. Weatherston. J. Chem. Ecol. 4, 109 (1978).

80. P.I. Svirskaya, C.C. Leznoff, J. Weatherston, and J.E. Laing. J. Chem. Eng. Data, 24, 152 (1979).

81. T.-H. Chan and W.-Q. Huang. J. Chem. Soc. Chem. Commun. 909 (1985).

82. J.M. Montierth, D.R. DeMario, M.J. Kurth, and N.E. Schore. Tetrahedron, 54, 11741 (1998).

83. (a) P.I. Svirskaya, C.C. Leznoff, and W.L. Roelofs. Synth. Commun. 10, 391 (1980); (b) P.I. Svirskaya, S.N. Maiti, A.J. Jones, B. Khouw, and C.C. Leznoff. J. Chem. Ecol. 10, 795 (1984).

84. M. Kawana and S. Emoto. Tetrahedron Lett. 4855 (1972).

85. (a) D. Enders and H.E. Eichenauer. Angew. Chem. Int. Ed. Engl. 15, 549 (1976); (b) A.I. Meyers, D.R. Williams, and M. Druelinger. J. Am. Chem. Soc. 98, 3032 (1976); (c) J.K. Whitesell and M.A. Whitesell. J. Org. Chem. 42, 377 (1977).

86. (a) P.M. Worster, C.R. McArthur, and C.C. Leznoff. Angew. Chem. Int. Ed. Engl. 18, 221 (1979); (b) C.R. McArthur, P.M. Worster, J.-L. Jiang, and C.C. Leznoff. Can. J. Chem. 60, 1836 (1982).

87. L. Duhamel and J.-C. Plaquevent. Bull. Soc. Chim. Fr. II-75 (1982).

88. C.R. McArthur, J.-L. Jiang, and C.C. Leznoff. Can. J. Chem. 60, 2984 (1982).

89. (a) S.J. Blazka and H.J. Harwood. Polym. Prep. Am. Chem. Soc. Div. Polym. Chem. 16, 633 (1975); (b) J. Rebek and F. Gaviña. J. Am. Chem. Soc. 96, 7112 (1974); (c) F. Gaviña, P. Gil, and B. Palazón. Tetrahedron Lett. 1333 (1979); (d) T.J. Nieuwstad, A.P.G. Kieboom, A.J. Breijer, J. van der Linden, and H. van Bekkum. Recl. Trav. Chim. Pays-Bas 95, 225 (1976).

90. V. Yedidia and C.C. Leznoff. Can. J. Chem. 58, 1144 (1980).

91. M.D. Corbridge, C.R. McArthur, and C.C. Leznoff. React Polym., 8, 173 (1988).

92. K. Bust, M. Christl, R. Huisgen, W. Mack, and R. Sustmann. Chem. Ber. 106, 3258 (1973).

93. M. Christl, R. Huisgen, and R. Sustmann. Chem. Ber. 106, 3275 (1973).

94. R.G. Little, J. Anton, P. Loach, and J.A. Ibers. J. Heterocycl. Chem. 12, 343 (1975).

95. C.C. Leznoff and P.I. Svirskaya. Angew. Chem. Int. Ed. Engl. 17, 947 (1978).

96. (a) C.C. Leznoff and T.W. Hall. Tetrahedron Lett. 23, 3023 (1982); (b) T.W. Hall, S. Greenberg, C.R. McArthur, B. Khouw, and C.C. Leznoff. Nouv. J. Chim. 6, 653 (1982).

97. D. Wöhrle and G. Krawczyk. Polym. Bull. 15, 193 (1986).

98. C.C. Leznoff, P.I. Svirskaya, B. Khouw, R.L. Cerny, P. Seymour, and A.B.P. Lever. J. Org. Chem. 56, 82 (1991).

99. P. Rothemund, J. Am. Chem. Soc. 57, 2010 (1935).

100. A.D. Adler, F.R. Longo, J.D. Finarelli, J. Goldmacher, J. Assour, and L. Korsakoff. J. Org. Chem. 32, 476 (1967).

101. (a) R.P. Linstead and A.R. Rowe. J. Chem. Soc. 1022 (1934); (b) P.A. Barrett, D.A. Frye, and R.P. Linstead. J. Chem. Soc. 1157 (1938).

102. M.J. Plunkett and J.A. Ellman. J. Org. Chem. 60, 6006 (1995).

103. (a) B.A. Lorsbach, R.B. Miller, and M.J. Kurth. J. Org. Chem. 61, 8716 (1996); (b) M.J. Kurth, L.A.A. Randall, and K. Takenouchi. J. Org. Chem. 61, 8755 (1996); (c) T. Ruhland, K. Anderson, and H. Pedersen. J. Org. Chem. 63, 9204 (1998).

104. (a) I. Ugi, S. Lohberger, and R. Karl. In Comprehensive organic synthesis. Edited by B.M. Trost and I. Fleming. Pergamon, New York. 1991. Vol. 2. p. 1083; (b) B.P. Coppola, M.C. Noe, D.J. Schwartz, R.L. Il Abdon, and B.M. Trost. Tetrahedron, 50, 93 (1994); (c) R.W. Armstrong, A.P. Combs, P.D. Tempest, S.D. Brown, and T.A. Keating. Acc. Chem. Res. 29, 123 (1996).

105. (a) N.E. Schore and S.D. Najdi. J. Am. Chem. Soc. 112, 441 (1990).

106. (a) M.S. Deshpande. Tetrahedron Lett. 35. 5613 (1994); (b) B.J. Backes and J.A. Ellman. J. Am. Chem. Soc. 116, 11171 (1994); (c) B.A. Lorsbach, J.T. Bagdanoff, R.B. Miller, and M.J. Kurth. J. Org. Chem. 63, 2244 (1998).

107. (a) M.A. Blaskovich and M. Kahn. J. Org. Chem. 63, 1119 (1998); (b) H.D. Piscopio, J.F. Miller, and K. Koch. Tetrahedron Lett. 39, 2667 (1998); (c) C.W. Phoon and C. Abell. Tetrahedron Lett. 39, 2655 (1998); (d) X. Du and R.W. Armstrong. J. Org. Chem. 62, 5678 (1997).

108. (a) A.R. Brown, P.H.H. Hermkens, H.C.J. Ottenheijm, and D.C. Rees. Synlett, 817 (1998); (b) L.A. Thompson and J.A. Ellman. Chem. Rev. 96, 555 (1996).

109. (a) Combinatorial peptide and nonpeptide libraries: a handbook. Edited by G. Jung. VCH, Weinheim. 1996; (b) Combinatorial chemistry. Synthesis and applications. Edited by S.R. Wilson and A.W. Czarnik. Wiley, New York. 1997.

110. C.C. Leznoff. In Phthalocyanines: properties and applications. Edited by C.C. Leznoff and A.B.P. Lever. VCH, New York. 1989. pp. 1-54.

111. C.C. Leznoff and A.B.P. Lever (Editors). Phthalocyanines: properties and applications. Vol. 1-4. VCH, New York. 1989, 1992, 1993, 1996.

112. F.H. Moser and A.L. Thomas (Editors). The Phthalocyanines. Vol. 1-2. CRC Press. Boca Raton, Fla. 1983. 
113. N.B. McKeown. Phthalocyanine materials, synthesis, structure and function. Cambridge University Press, Cambridge. 1998.

114. (a) F.P. Schwartz, M. Gouterman, Z. Murjiana, and D.H. Dolphin. Bioinorg. Chem. 2, 1 (1972); (b) J. Hiom, J.B. Paine, III, V. Zapf, and D. Dolphin. Can. J. Chem. 61, 2220 (1983).

115. (a) J.P. Collman, F.C. Anson, S. Bencosme, A Chong, T. Collins, P. Denisevich, E. Evitt, T. Geiger, J.A. Ibers, G. Jameson, Y. Konai, C. Koval, K. Meier, P. Oakley, R.B. Pettman, E. Schmittov, and J. Sessler. In Organic synthesis today and tomorrow. Edited by B.M. Trost and C.R. Hutchinson. Pergamon, Oxford. 1981. pp. 29-45; (b) J.P. Collman, F.C. Anson, C.E. Barnes, C.S. Bencosme, T. Geiger, R.E. Evitt, R.P. Krch, K. Meier, and R.B. Pettman. J. Am. Chem. Soc. 105, 2694 (1983).

116. (a) C.K. Chang. J. Am. Chem. Soc. 99, 2819 (1977); (b) R. Karaman, S. Jeon, O. Almarsson, and T.C. Bruice. J. Am. Chem. Soc. 114, 4899 (1992); (c) Z. Asfari, J. Vicens, and J. Weiss. Tetrahedron Lett. 34, 627 (1992).

117. C.C. Leznoff, S. Greenberg, S.M. Marcuccio, P.C. Minor, P. Seymour, and A.B.P. Lever. Inorg. Chim. Acta. 89, L35 (1984).

118. C.C. Leznoff, S.M. Marcuccio, S. Greenberg, A.B.P. Lever, and K.B. Tomer. Can. J. Chem. 63, 623 (1985).

119. C.C. Leznoff, S. Greenberg, P.I. Svirskaya, K.B. Tomer, and A.B.P. Lever. Can. J. Chem. 63, 3057 (1985).

120. E.S. Dodworth, A.B.P. Lever, P. Seymour, and C.C. Leznoff. J. Phys. Chem. 89, 5698 (1985).

121. S. Greenberg, S.M. Marcuccio, C.C. Leznoff, and K.B. Tomer. Synthesis, 406 (1986).

122. (a) C.C. Leznoff, H. Lam, S.M. Marcuccio, W.A. Nevin, P. Janda, N. Kobayashi, and A.B.P. Lever. J. Chem. Soc. Chem. Commun. 699 (1987); (b) S. Vigh, H. Lam, P. Janda, A.B.P. Lever, C.C. Leznoff, and R.L. Cerny. Can. J. Chem. 69, 1457 (1991).

123. H. Isago, D.S. Terekhov, and C.C. Leznoff. J. Porphyrins Phthalocyanines, 1, 135 (1997).

124. H. Lam, S.M. Marcuccio, P.I. Svirskaya, S. Greenberg, A.B.P. Lever, C.C. Leznoff, and R.L. Cerny. Can. J. Chem. 67, 1087 (1989).
125. C.C. Leznoff, H. Lam, W.A. Nevin, N. Kobayashi, P. Janda, and A.B.P. Lever. Angew. Chem. Int. Ed. Engl. 26, 1021 (1987).

126. J. Li. Ph.D. Thesis, York University, Toronto, Canada. 1993.

127. W.A. Nevin, W. Liu, S. Greenberg, M.R. Hempstead, S.M. Marcuccio, M. Melnik, C.C. Leznoff, and A.B.P. Lever. Inorg. Chem. 26, 891 (1987).

128. (a) W. Liu, M.R. Hempstead, W.A. Nevin, M. Melnik, A.B.P. Lever, and C.C. Leznoff. J. Chem. Soc. Dalton Trans. 25I1 (1987); (b) W.A. Nevin, M.R. Hempstead, W. Liu, C.C. Leznoff, and A.B.P. Lever. Inorg. Chem. 26, 570 (1987); (c) M.R. Hempstead, A.B.P. Lever, and C.C. Leznoff. Can. J. Chem. 65, 2677 (1987).

129. (a) W.A. Nevin, M.R. Hempstead, W. Liu, C.C. Leznoff, and A.B.P. Lever. Inorg. Chem. 26, 570 (1987); (b) W. Manivannan, W.A. Nevin, C.C. Leznoff, and A.B.P. Lever. J. Coord. Chem. 19, 139 (1988); (c) P. Janda, N. Kobayashi, P.R. Auburn, H. Lam, C.C. Leznoff, and A.B.P. Lever. Can. J. Chem. 67, 1109 (1989); (d) N. Kobayashi, H. Lam, W.A. Nevin, P. Janda, C.C. Leznoff, and A.B.P. Lever. Inorg. Chem. 29, 3415 (1990); (e) N. Kobayashi, H. Lam, W.A. Nevin, P. Janda, C.C. Leznoff, T. Koyama, A. Monden, and H. Shirai. J. Am. Chem. Soc. 116, 879 (1994).

130. J.H. Kim, T.M. Cotton, R.A. Uphaus, and C.C. Leznoff. Thin Solid Films, 159, 141 (1988).

131. D.S. Terekhov, K.J.M. Nolan, C.R. McArthur, and C.C. Leznoff. J. Org. Chem. 61, 3034 (1996).

132. (a) C.C. Leznoff, Z. Li, H. Isago, A.M. D'Ascanio, and D.S. Terekhov. J. Porphyrins Phthalocyanines, 3, 406 (1999); (b) H. Isago, C.C. Leznoff, M.F. Ryan, R.A. Metcalfe, R. Davids, and A.B.P. Lever. Bull. Chem. Soc. Jpn. 71, 1039 (1998); (c) K.J.M. Nolan and C.C. Leznoff. Synlett, 593 (1997).

133. (a) H. Naarmann and M. Hanack. Chem. Abstr. 115 P208923d (1991); (b) E.M. Maya, P. Haisch, P. Vazquez, and T. Torres. Tetrahedron, 54, 4397 (1998).

134. H.S. Nalwa and J.S. Shirk. In Phthalocyanines: properties and applications, Vol 4. Edited by C.C. Leznoff and A.B.P. Lever, VCH, New York. 1996.

135. B. Suchozak. M.Sc. Thesis, York University, Toronto, Canada. 1999. 